\title{
A Groundwater Monitoring Design through Site Characterization, Numerical Simulation and Statistical Analysis - A North American Case Study
}

\author{
I. Maqsood, G. H. Huang* and Y. F. Huang \\ Environmental Systems Engineering Program, Faculty of Engineering, University of Regina, Regina, SK S4S 0A2, Canada
}

\begin{abstract}
Groundwater monitoring facilitates efficient aquifer remediation to better protect the public health and the environment. An efficient design could answer important monitoring-data questions, such as (a) is the trend in the groundwater data significant; (b) how important is each well in the trend analysis; (c) what is the suggested future monitoring well density, sampling frequency and duration; (d) what contaminants of concern need to be monitored at the site; and (e) what depth is appropriate to take samples. In this study, groundwater-monitoring plans are designed for a petroleum-contaminated site in western Canada. The plans are based on the site characterization, contaminants transport modeling in groundwater under various remediation scenarios, and optimization of the monitoring network using the existing site infrastructure and statistical trend analysis. The plans can reflect dynamic characteristics of the site and present a declining pattern of sampling frequency associated with a rising trend of the site restoration. The study provides bases for long-term monitoring decisions at contaminated sites.
\end{abstract}

Keywords: Contamination, groundwater, monitoring design, numerical simulation, remediation, site characterization

\section{Introduction}

Groundwater monitoring is an essential task at contaminated sites. It plays an important role in providing insight into the site-contamination situation, tracking the migration of contaminant plumes, supporting fate and transport modeling, performing risk assessment, and designing remedial plans. A properly designed monitoring network helps facilitate efficient aquifer remediation to better protect human health and the environment. However, monitoring of contaminated sites is a significant cost driver for future environmental restoration activities. Although an individual long-term monitoring data point is relatively small, the scale of the required data-collection effort and the time commitment makes the cumulative costs very high (AFCEE, 1997). Thus, efficient monitoring-network plans are desired.

Previously, several studies of monitoring network design were undertaken (Rouhani \& Hall, 1988; Andricevic \& Foufoula-Georgiou, 1991; Loaiciga, 1992; Hudak \& Loaiciga, 1993; Zhou, 1994; Beckie, 1996; AFCEE, 1997; Hudak, 1999; NFESC, 2000; Hudak, 2002). Most of these designs were based on statistical methods (Angulo \& Tang, 1996; Ridley \& MacQueen, 1998; Rasula \& Rasula, 2001) or simulation-optimization approaches (Cieniawski, 1995; Wagner 1995; Reed et al., 2000, 2001). For example, Grabow et al. (1993) proposed a groundwater monitoring network design using minimum well density. Meyer et al. (1994) presented a monitoring network design to provide initial detection of groundwater contamination. Reed et al.

\footnotetext{
* Corresponding author: gordon.huang@uregina.ca
}

(2000) developed a cost-effective groundwater monitoring design using a genetic algorithm and global mass interpolation. Zhang and Pinder (2002) designed optimal groundwater-quality monitoring networks via computer assisted analysis. However, the previous designs were either based on data-driven or simulation-optimization approaches and there were no comprehensives studies considering site characterization, simulation, optimization, and statistical trend analysis combined within a single frame. Moreover, many existing groundwater monitoring programs did not reflect changes in the site conditions or compliance attainment. Therefore, dynamic monitoring designs based on both data-driven and simulation-optimization approaches as well as site characterization are desired for improving existing groundwater monitoring plans.

As an intension of the previous studies, an integrated approach will be proposed to design groundwater monitoring networks through the incorporation of site characterization, numerical simulation, system optimization, statistical trend analysis, and dynamic design into a single frame. The approach will be applied to design groundwater-monitoring plans for a petroleum-contaminated site in western Canada. The objective entails (a) characterization of the site, (b) numerical simulation of the contaminants transport in groundwater under various remediation scenarios, and (c) design and optimization of monitoring network using the existing site infrastructure and statistical trend analysis. The plan will provide the minimum number of sampling locations and the optimal frequency of sampling for long-term monitoring at the site. These plans will reflect dynamic characteristics of the site. Moreover, the study will provide a 
basis for long-term monitoring decisions for the site. The plan will be useful for tracking the changes in shape, size, or position of the contaminant plume; tracking contaminants exceeding the standards; and assessing the performance of the remedial studies.

\section{Site Characterization}

The study site (Cantuar Gas Plant Site), located in western Canada (Figure 1), has been operated as processing plant to remove naphtha condensate from the natural gas stream prior to transporting to a regional transmission line. Throughout the site history, naphtha condensate, which is a waste liquid removed from the gas by a series of scrubbers, was disposed of in an underground storage tank (UST). For many years natural gas condensates has been leaking from the UST into the soil and then to the groundwater. In1996, monitoring wells were installed adjacent to the UST and displayed up to one meter of naphtha during the subsequent monitoring events. It was determined that the leaking UST had impacted a large area and the contaminants had the potential to move off the site to the west. The UST therefore was decommissioned and additional boreholes were completed to delineate the extent of the hydrocarbon-impacted area. Recently, naphtha condensate was disposed of in an above ground storage tank (AST) located southeast of the pump/scrubber building. The current infrastructure at the site is shown in Figure 2.

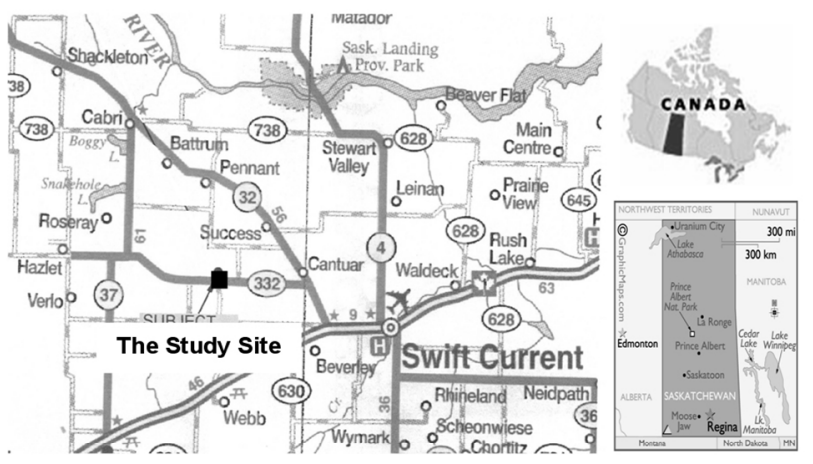

Figure 1. The study site.

The surficial units at the site consist of topsoil to a maximum depth of $0.5 \mathrm{~m}$ below ground level (mBGL). Underlying the topsoil is native silty clay and sand between 4 and $14 \mathrm{~m}$, and clay till extending beyond 14 mBGL. In some areas, a sand layer is interbedded in or underlying the clay till at 6.5 to $21 \mathrm{mBGL}$ (Figure 3). A summary of the site conditions is provided in Table 1 . The general groundwater flow direction is towards the northwest. Water table elevations encountered in the sand and clay-till soils are at 11.60 to $12.25 \mathrm{mBGL}$ with a slight southwesterly gradient. Monitoring wells established at the overlying silty clay indicated water table elevations of 91.2 to $91.6 \mathrm{~m}$ (8.4 to 8.8 mBGL) (Figure 4).
Table 1. Summary of the Site Conditions

\begin{tabular}{ll}
\hline Parameter & Value \\
\hline Soil classification & Silty clay, sand, and clay till \\
Hydraulic conductivity & $10^{-7}-10^{-5} \mathrm{~m} / \mathrm{s}$ \\
Moisture content (by volume) & $7.5-325 \%$ \\
Porosity & $30-53.1 \%$ \\
Groundwater table (below & $4.8-13.2 \mathrm{~m}$ \\
ground surface) & $7.7-9.1$ \\
PH of groundwater & $1.0-1.5 \mathrm{mg} / \mathrm{L}$ \\
Dissolved oxygen concentration & $\mathrm{C}_{5}-\mathrm{C}_{10} \mathrm{hydrocarbons}$ \\
Contaminants & Trace to $>1800 \mathrm{~mm}$ \\
Hydrocarbon free product & $>10,000 \mathrm{ppm}$ \\
Hydrocarbon vapor concentration & $2000 \mathrm{~kg} / \mathrm{m}^{3}$ \\
Hydrocarbon bulk density & $3500 \mathrm{~m}^{2}$ \\
\hline
\end{tabular}

Free products (or liquid phase hydrocarbons) resembling naphtha were identified in the monitoring wells located onsite and offsite. In 2001, liquid phase hydrocarbons were encountered in many monitoring wells (Figure 5). The monitoring results helped identify a total volume of 55,000 $\mathrm{L}$ hydrocarbons and an estimated 2,800 $\mathrm{L}$ of recoverable free products, prior to any remedial activities. Residualphase hydrocarbons were encountered in soil samples collected during the drilling program. The concentrations of benzene, toluene, ethyl-benzene, xylenes (BTEX) and total petroleum hydrocarbons (TPH) were found higher than the local environmental guidelines. An approximate lateral extent of residual hydrocarbons is shown in Figure 2. The groundwater sampling results indicated that BTEX concentrations were higher than the local potable groundwater quality guidelines.

In general, a highly concentrated contamination zone exists at the vicinity of the UST. The groundwater flow and contaminant plume gradient are towards the northwest. The free products are in the range of light hydrocarbons, being similar to naphtha. BTEX and TPH concentrations in groundwater are from non-detectable to above the environmental guidelines.

\section{Numerical Simulation}

\subsection{DPVE Process Simulation and 3D Multiphase Multi-component Modeling}

A three-dimensional multiphase and multicomponent model is employed to simulate contaminant transport in subsurface to facilitate system forecasting under different Dual Phase Vacuum Extraction (DPVE) process-control alternatives (Maqsood et al., 2003; Li et al., 2003). The site is 


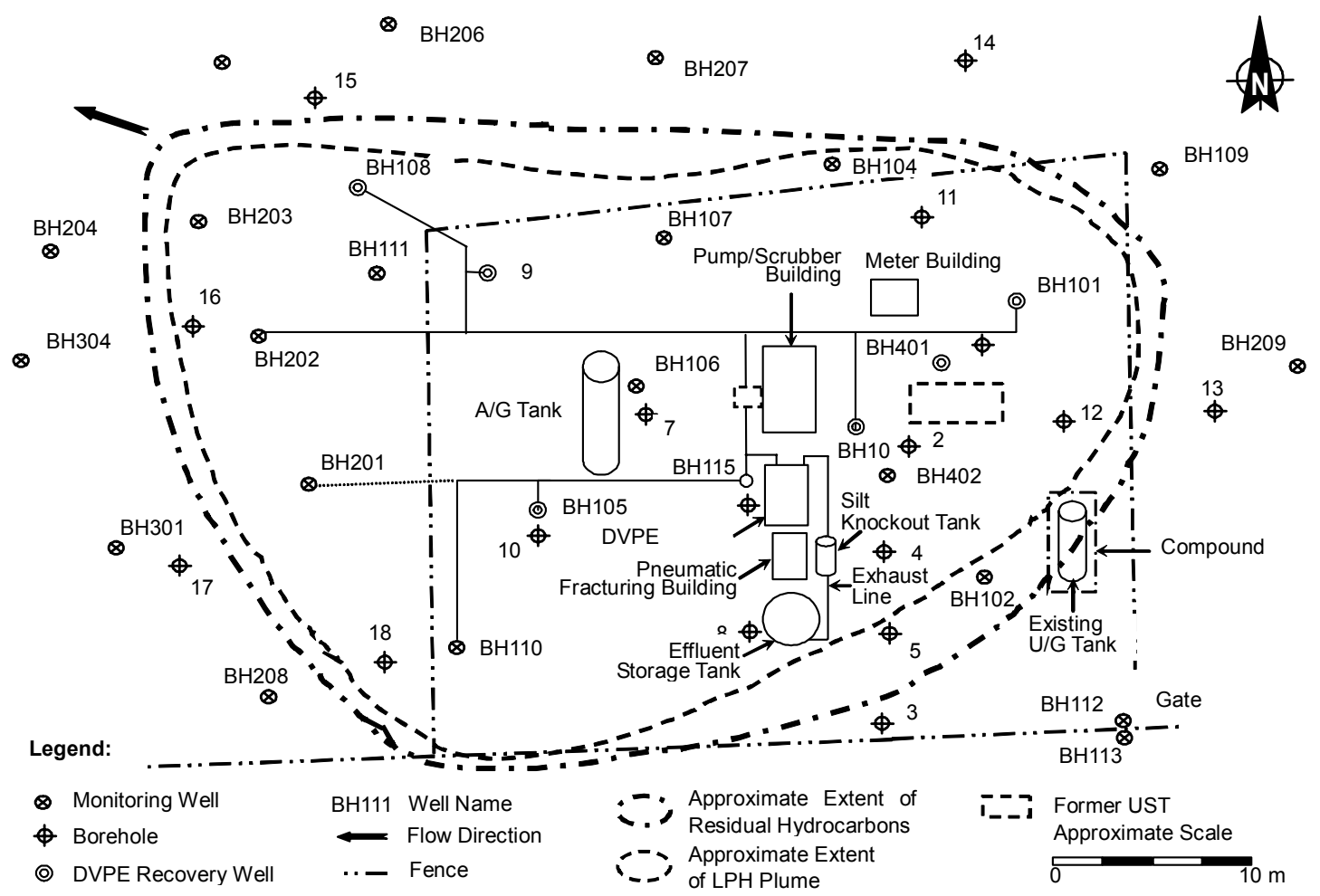

Figure 2. The site plan.

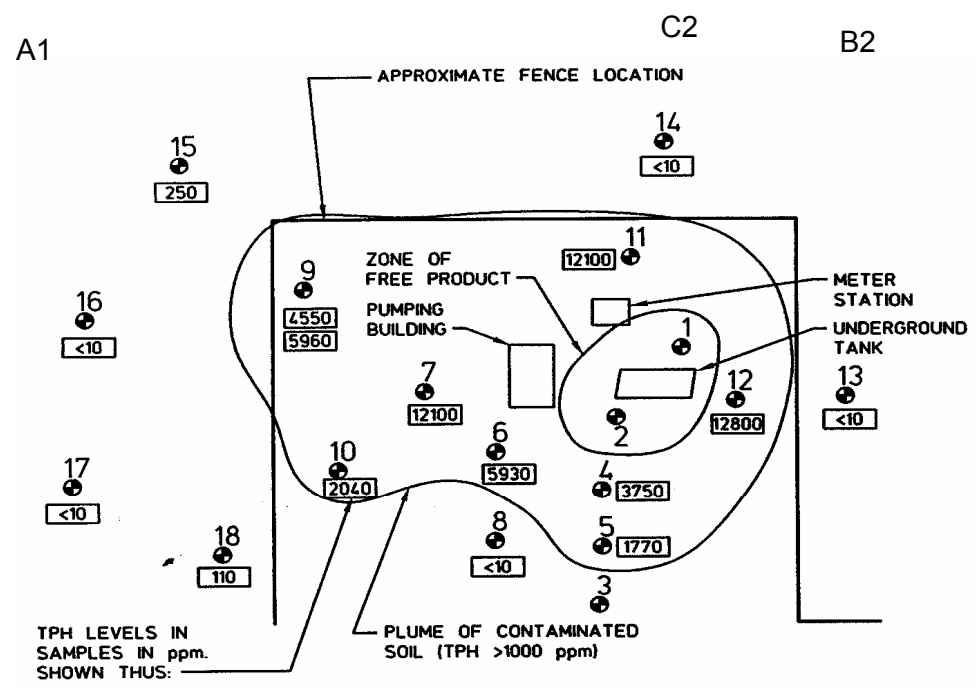

B1

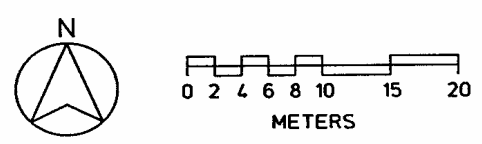

C1

Figure 3(a). Distribution of boreholes. 


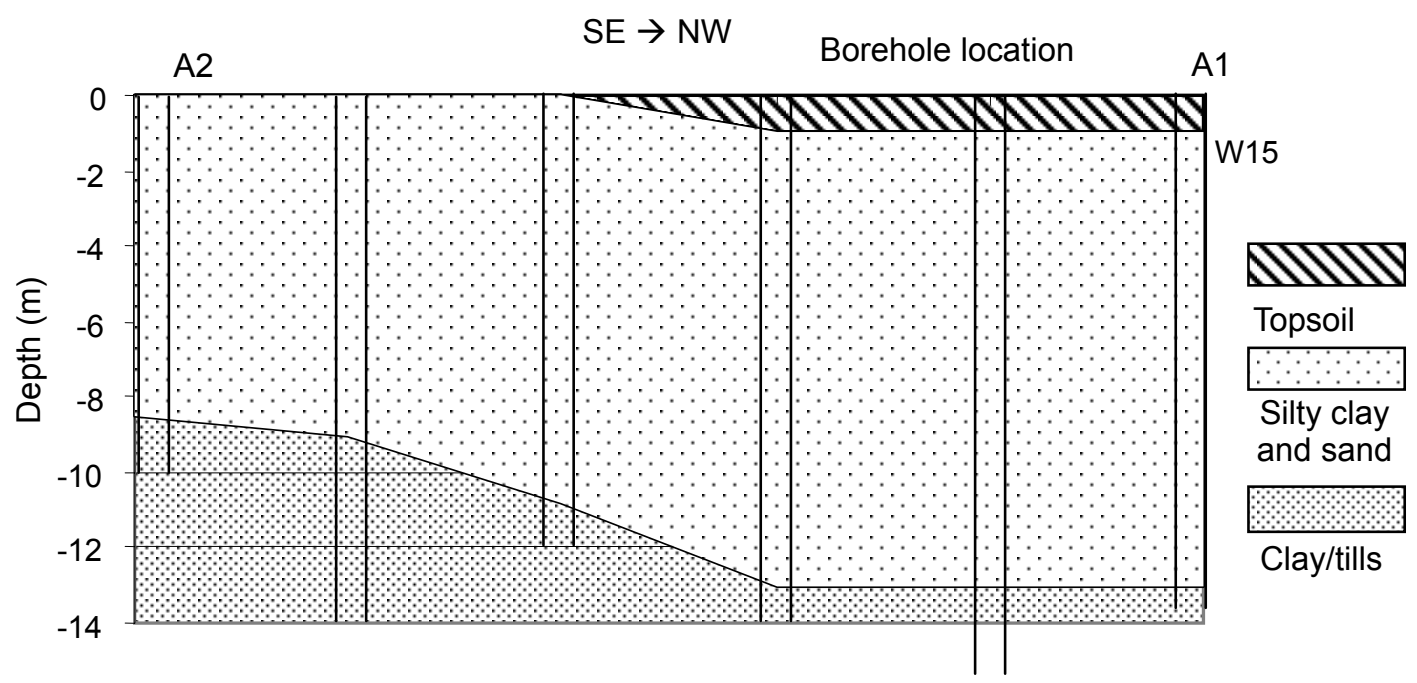

Figure 3(b). Stratigraphic cross section of A1A2.

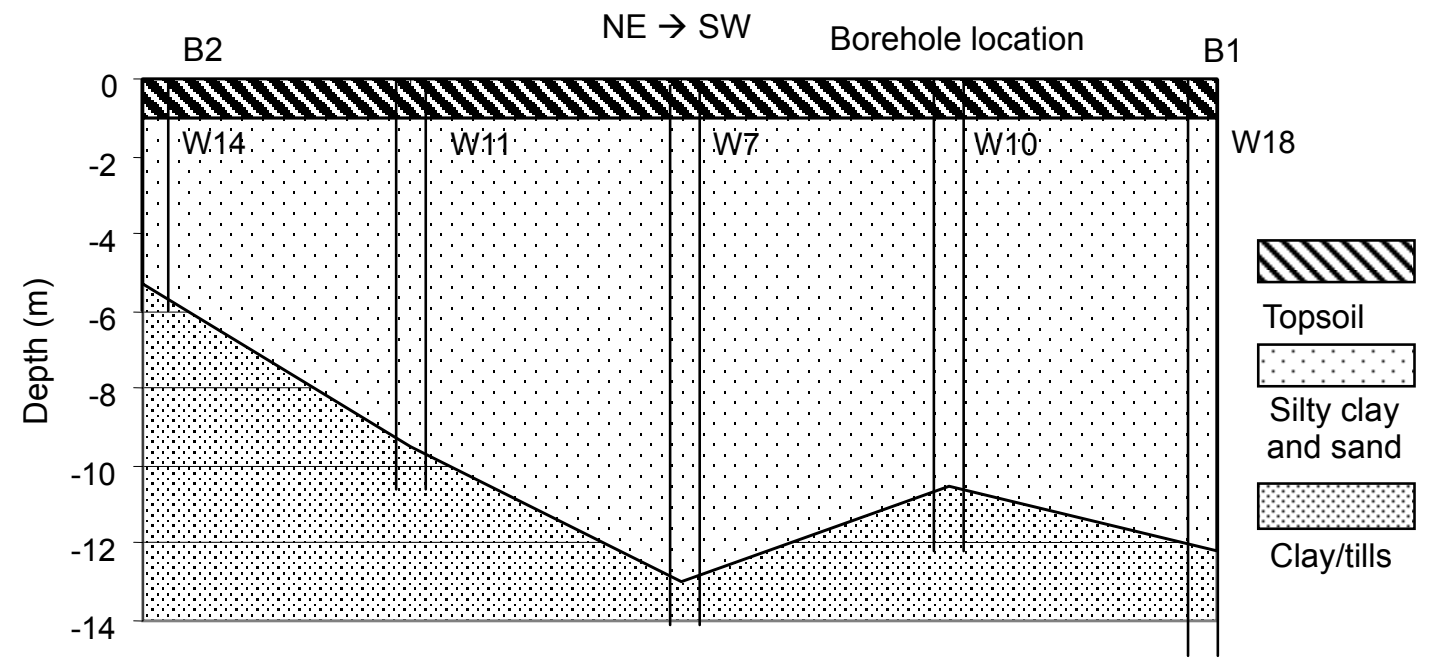

Figure 3(c). Stratigraphic cross section of B1B2.

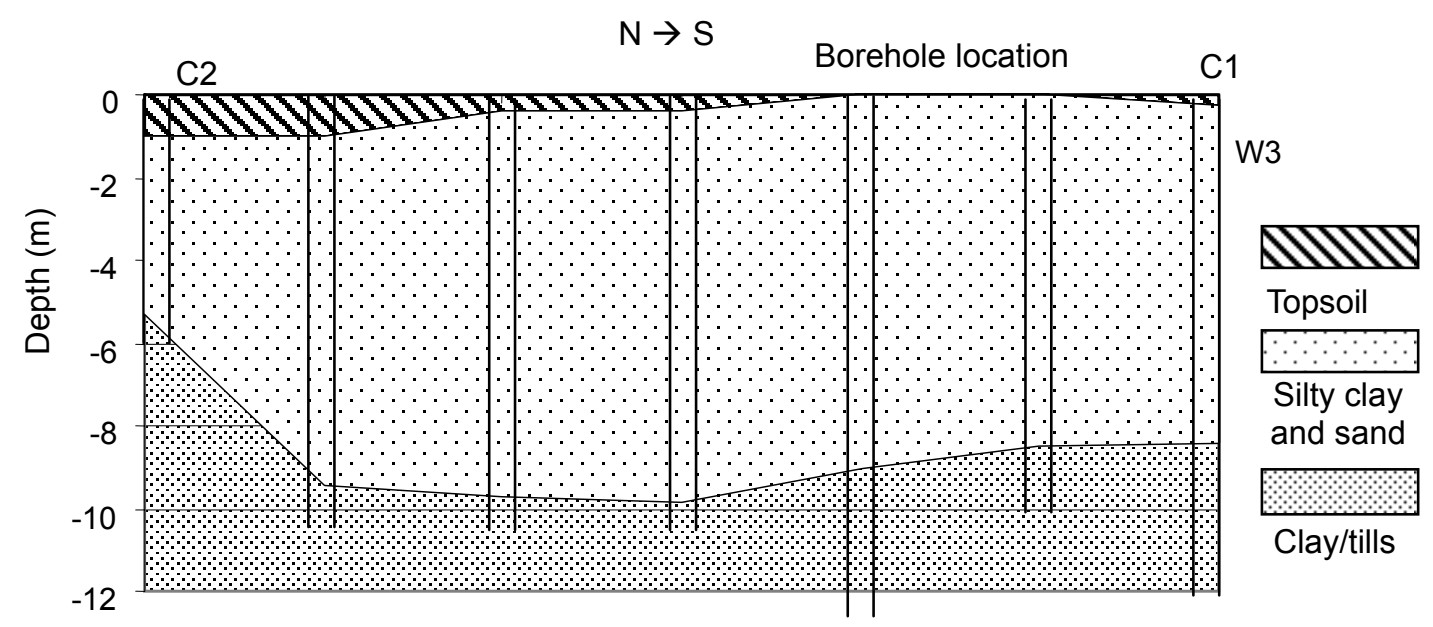

Figure 3(d). Stratigraphic cross section of C1C2. 


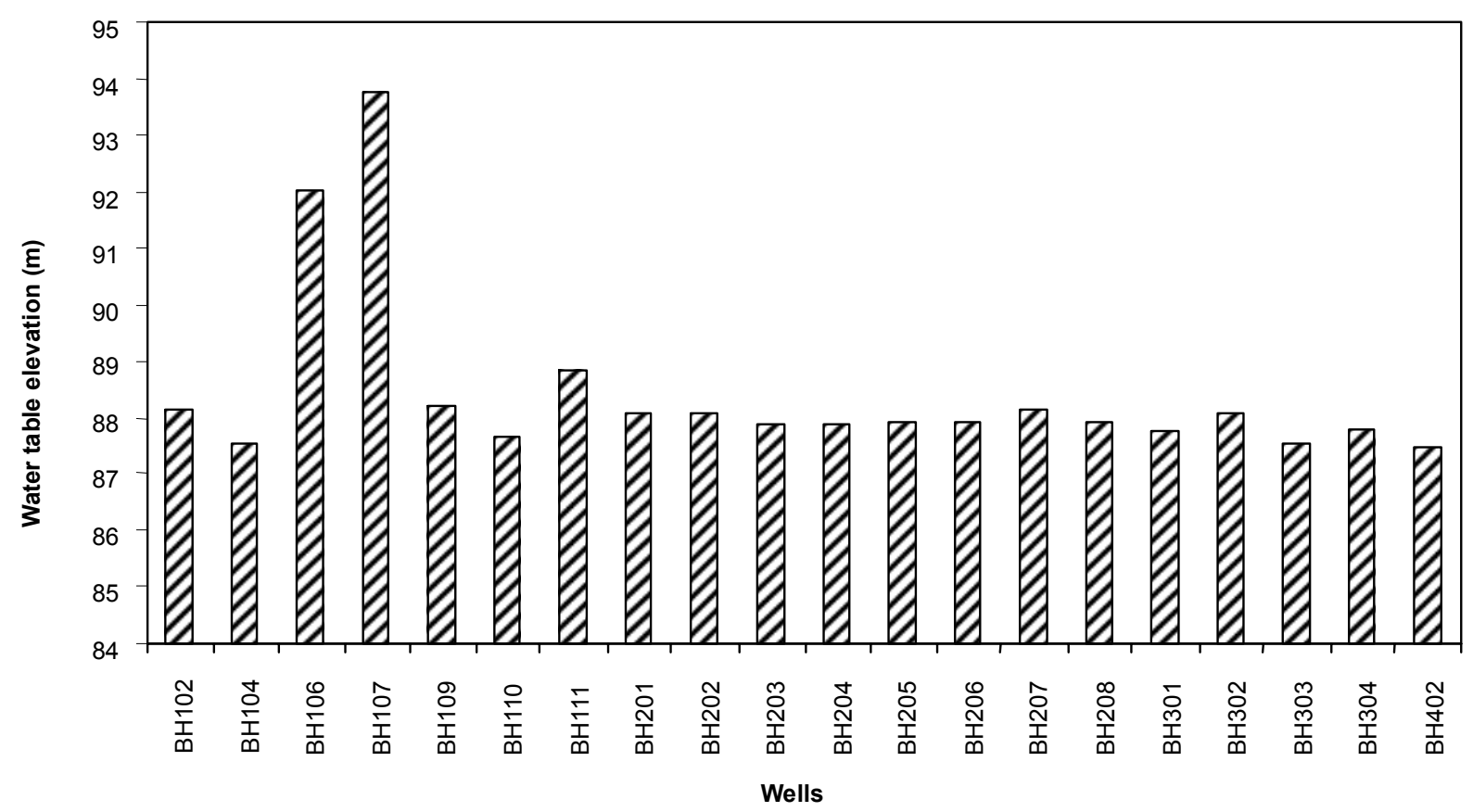

Figure 4. Spatial fluctuations of groundwater table elevation on October 12, 2001.

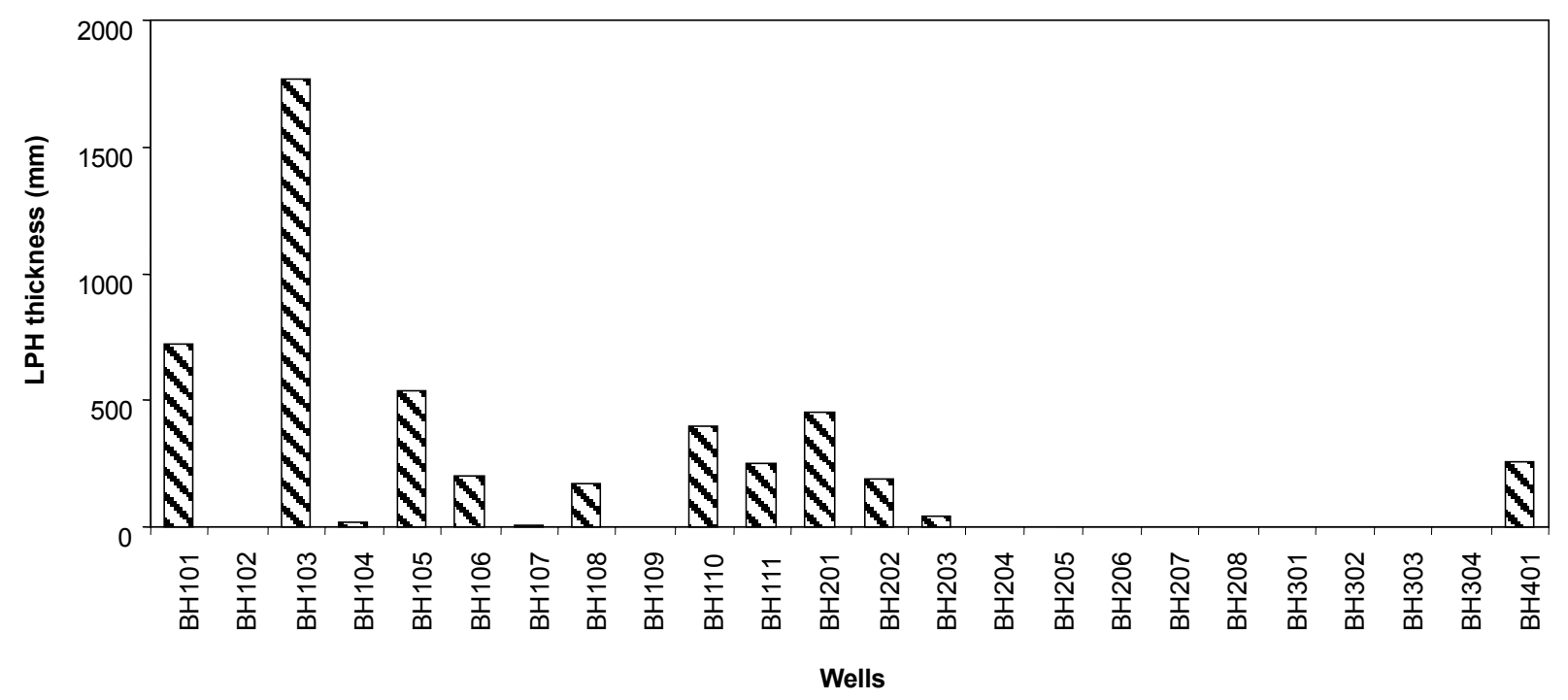

Figure 5. Spatial variations in liquid phase hydrocarbon (LPH) thickness in 2001. 

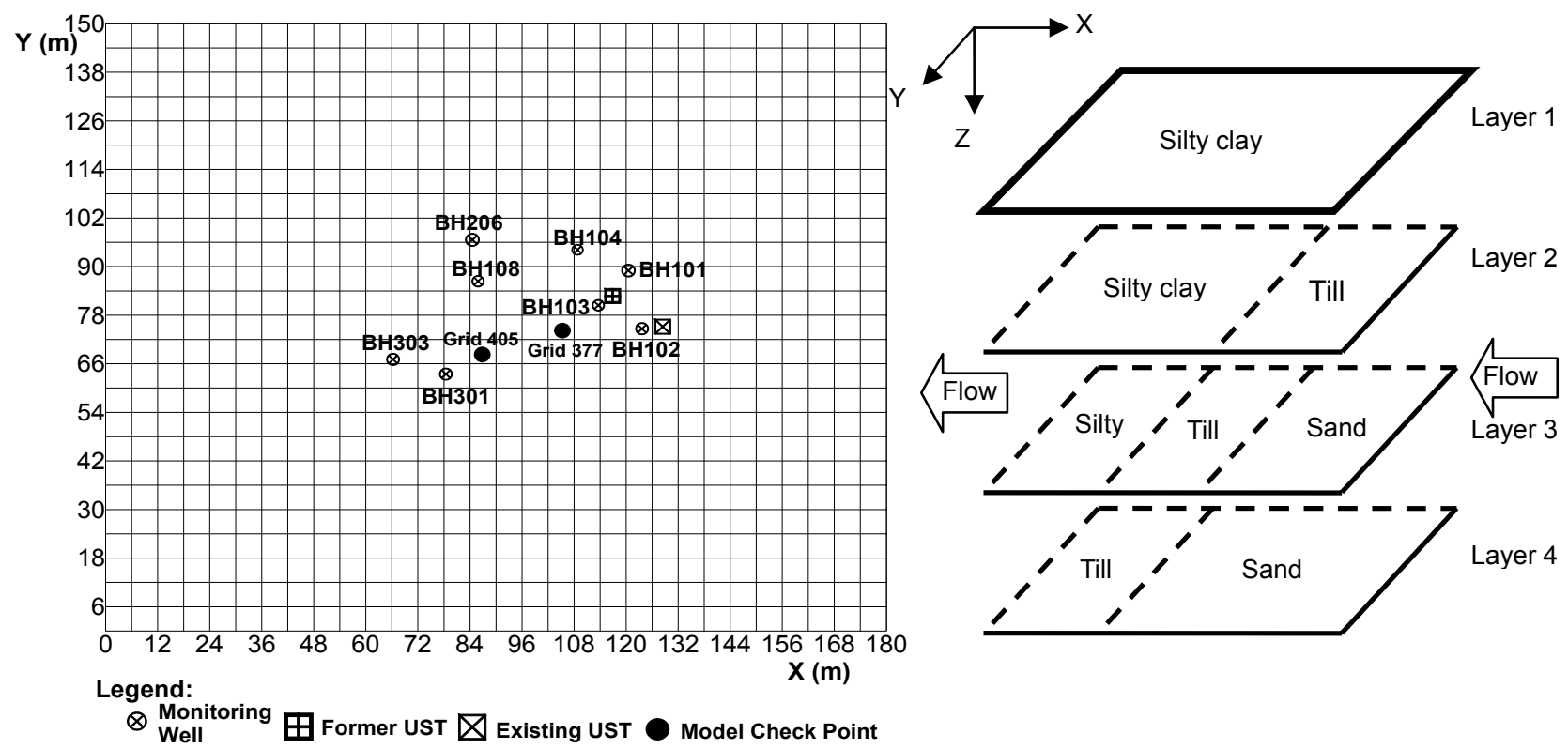

Figure 6. Simulation domain of the site and soil property in the simulation domain.

Table 2. Part of Modeling Input Parameters

\begin{tabular}{ll}
\hline Parameter & Value \\
\hline Residual water / oil / gas saturations & $0.1 / 0.2 / 0.1$ \\
Permeability of sandy / clay till / silty clay soils & $29000 / 195 / 380 \mathrm{MD}$ \\
Porosity of sandy / clay till / silty clay soils & $0.35 / 0.30 / 0.53$ \\
NAPL/water interfacial tension & 45 Dynes/cm \\
NAPL density & $0.713 \mathrm{~g} / \mathrm{cm}^{3}$ \\
Longitudinal dispersivity of sandy / clay till / silty clay soils & $5 / 5 / 5 \mathrm{~m}$ \\
Transverse dispersivity of sandy / clay till / silty clay soils & $0.5 / 0.5 / 0.5 \mathrm{~m}$ \\
Hydraulic gradient & $0.006 \mathrm{~m} / \mathrm{m}$ \\
NAPL/water partition coefficient of benzene & 0.00203 \\
NAPL/water partition coefficient of E-benzene & 0.000173 \\
NAPL/water partition coefficient of toluene & 0.000594 \\
NAPL/water partition coefficient of xylenes & 0.000175 \\
Benzene solubility & $1750 \mathrm{mg} / \mathrm{L}$ \\
Ethylbenzene solubility & $152 \mathrm{mg} / \mathrm{L}$ \\
Toluene solubility & $535 \mathrm{mg} / \mathrm{L}$ \\
Xylenes solubility & $175 \mathrm{mg} / \mathrm{L}$ \\
Time step at t=0 & $0.101 \mathrm{day}$ \\
Maximum time step size & $10 \mathrm{day}$ \\
Tolerance for concentration change & 0.001 \\
\hline
\end{tabular}


conceptualized into a three-dimensional domain, with an area of $180 \times 150 \mathrm{~m}^{2}$ (Figure 6). Vertically, the domain is discretized into four layers. Each layer has a depth of $5 \mathrm{~m}$ and an area of $180 \times 150 \mathrm{~m}^{2}$, and is discretized into $30 \times 25$ grid blocks. Each grid has dimensions of 6, 6, and $5 \mathrm{~m}$ in $\mathrm{x}$, $\mathrm{y}$, and $\mathrm{z}$ directions, respectively. The total number of grids in the 3 -D system are $3000(30 \times 25 \times 4)$. Layers 3 and 4 are located in the saturated zone, while layers 1 and 2 are in the unsaturated zone. The site possesses three soil types including sandy, clay till, and silty clay as shown in Figure 3.

The typical control parameters include simulation time horizon, allowable time increment, time interval to write effluent concentrations, number of time steps and iterations, termination constraints, domain types and definitions, flow or transport simulation selection control, and connection and communication between property data and numerical grids. Table 2 lists part of the modeling inputs. The input data were obtained from a number of sources after careful verification. Among them, reports of the previous site investigation, laboratory analysis, and modeling study are major sources.

\subsection{Model Calibration}

For the study site, benzene is the most critical contaminant; as long as its concentrations are lower than the relevant environmental criterion, the other contaminants (e.g. toluene, ethylbenzene, and xylenes) will then be of insignificant concern. Therefore, only simulation results of benzene concentrations are analyzed in this paper. The monitored benzene concentrations in 2000 are used for verifying the developed model. Figure 7 presents the predicted and monitored benzene concentrations in groundwater during September 2000. The errors between the simulated and observed concentrations range from -0.068 to $0.085 \mathrm{mg} / \mathrm{L}$, with a RMSE of $0.029 \mathrm{mg} / \mathrm{L}$, a mean absolute error of $-0.0024 \mathrm{mg} / \mathrm{L}$, and a mean relative error of $4.88 \%$. It is indicated that the model is capable of characterizing the plume boundary and shape. The predicted and observed maximum benzene concentrations are 429.78 and $345 \mu \mathrm{g} / \mathrm{L}$, respectively.

\subsection{Forecast of Contaminants under Different Remedia- tion Scenarios}

Several scenarios were studied to predict temporal and spatial distributions of the contaminants under different remediation options. In general, three questions are addressed by assuming that a 60-day of DPVE program will be continued after 2001: (a) without other remediation actions, what will happen 10, 20, 40, 60, 80, and 100 years later? (b) If a further remediation action with $60 \%$ efficiency is undertaken in 2002 to 2003, what will happen 10, 20, 40, 60,80 , and 100 years later? and (c) If a further remediation action with $90 \%$ efficiency is undertaken in 2002 to 2003 , what will happen 10,20 , and 40 years later?

\section{Option (a): A 60-day DPVE program only}

Figure 8 shows distributions of benzene concentration in the groundwater $10,20,40$, and 60 years later, with the peak concentrations being 403.0, 406.1, 306.6, and 87.1 $\mu \mathrm{g} / \mathrm{L}$, respectively. Figure 8(c) shows that the peak will not decrease significantly 40 years later, since hydrocarbons still exist in the unsaturated zone and will thus continuously move into the groundwater; but the plume boundary will start shrinking by that time. As shown in Figure $8(\mathrm{~d})$, the peak after 60 years will still be higher than the regulated 5 $\mu \mathrm{g} / \mathrm{L}$ in the local potable groundwater quality guidelines (SERM, 2002). The peak after 80 years (Figure not shown) will decrease signifycantly due to natural dispersion, biodegradation, and no further hydrocarbon will seep into

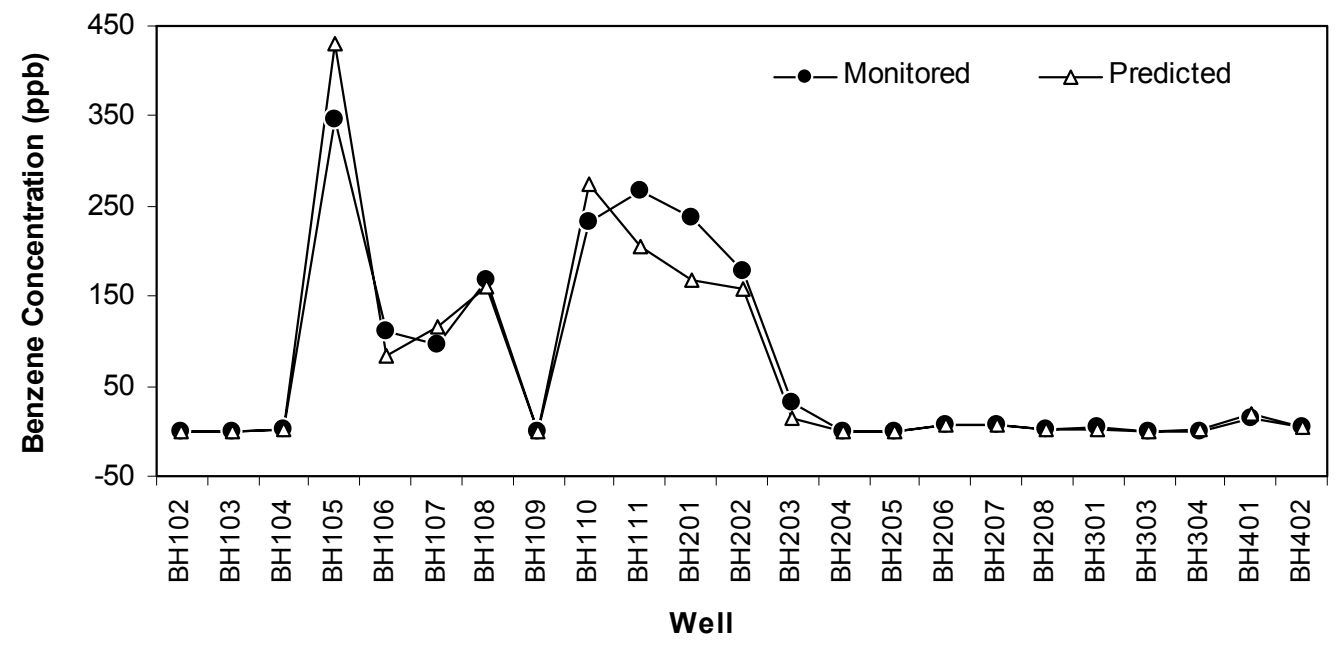

Figure 7. Comparison of the predicted and monitored results. 

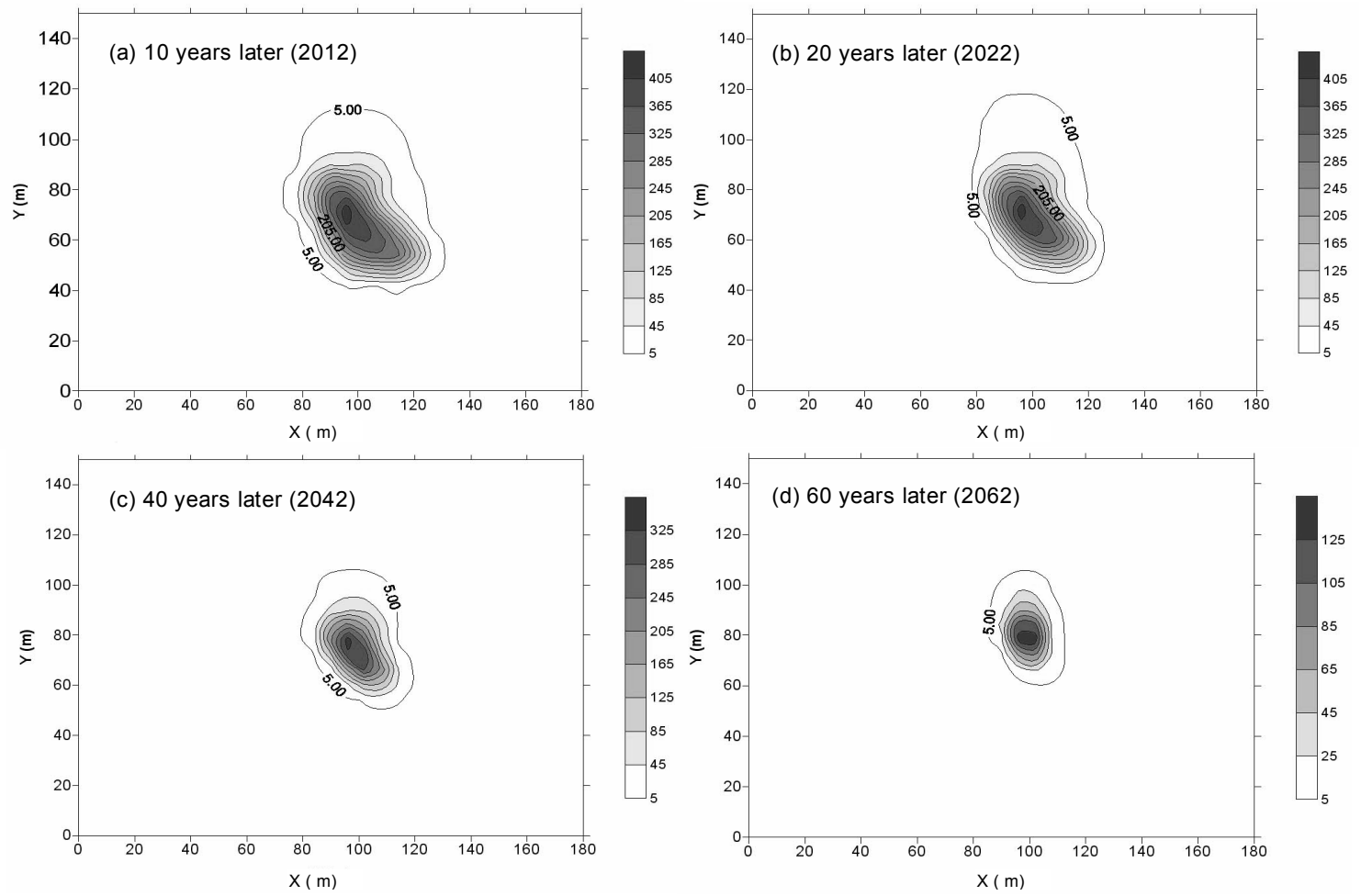

Figure 8. Predicted benzene concentrations (ppb) in groundwater under remediation option (a).
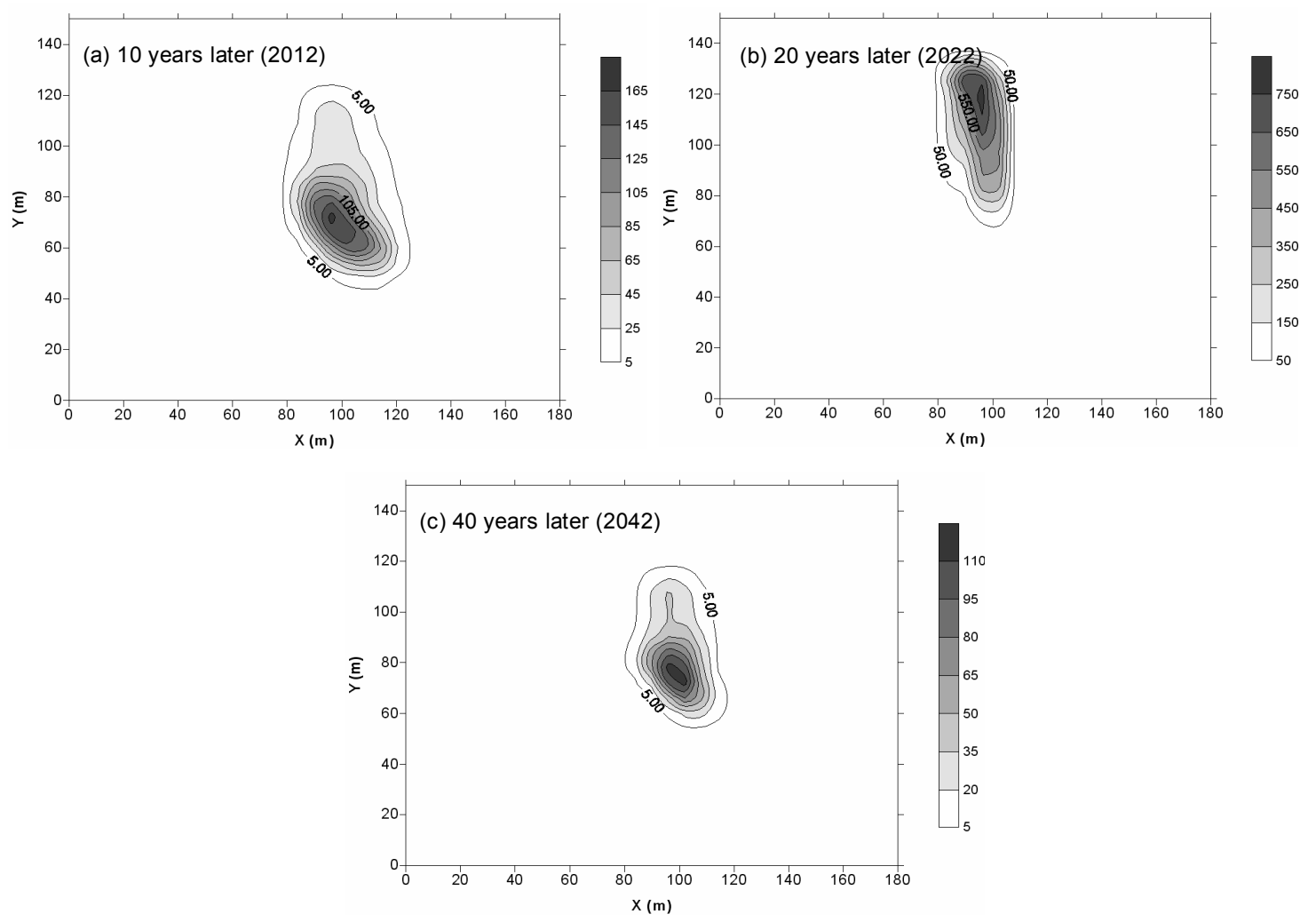

Figure 9. Predicted benzene concentrations (ppb) in Groundwater under remediation option (b). 
the groundwater from the unsaturated zone. The proportion of concentration reduction within the last 20 years (from 2062 to 2082) will be $98 \%$. In general, with a 60 -day DPVE program only after October 2001, the existing benzene will pose threats even 60 years later, but no threats 80 years later.

Option (b): A 60-day DPVE program followed by a futher remediation action with $60 \%$ efficiency

Figure 9 shows the distributions of benzene concentration in groundwater 10, 20 and 40 years later, with the peak concentrations being $162.5,101.3$ and $0.28 \mu \mathrm{g} / \mathrm{L}$, respectively. These are lower than the regulated $300 \mu \mathrm{g} / \mathrm{L}$ in the local freshwater/aquatic use groundwater quality guidelines (SERM, 2002); but the peak after 20 years will still be much higher than the regulated $5 \mu \mathrm{g} / \mathrm{L}$ in the local potable groundwater quality guidelines (SERM, 2002). The peak of $0.28 \mu \mathrm{g} / \mathrm{L}$ will be much lower than the regulated $5 \mu \mathrm{g} / \mathrm{L}$ in the local potable groundwater quality guidelines after 40 years (SERM, 2002). In general, with a 60-day DPVE program after October 2001, and a further 60\% efficiency remediation action, the existing benzene will pose threats even 20 years later; however, there will be no threats 40 years later.

\section{Option (c): A 60-day DPVE program followed by a further remediation action with $90 \%$ efficiency}

Figure 10 shows distributions of benzene concentration in the groundwater 10 and 20 years later, with the peak concentrations being 24.4 and $1.30 \mu \mathrm{g} / \mathrm{L}$, respectively. After 10 years, the peak will be much lower than the regulated $300 \mu \mathrm{g} / \mathrm{L}$ in the local freshwater/aquatic use groundwater quality guidelines (SERM, 2002), but higher than the regulated $5 \mu \mathrm{g} / \mathrm{L}$ in the local potable groundwater quality guidelines (SERM, 2002). After 20 years, the peak will be lower than the regulated $5 \mu \mathrm{g} / \mathrm{L}$ in the local potable groundwater quality guidelines (SERM, 2002). In general, with a 60-day DPVE program after October 2001, and a further $90 \%$ effi- ciency remediation action, the existing benzene will pose threats even 10 years later; however, it will not pose threats 20 years later.

\section{Sampling Network Design}

\subsection{Tasks of Monitoring Network Designs}

Before designing an effective monitoring program, one must ask, "what is the goal of monitoring at this site?" Knowing the monitoring goals in advance will help design an efficient monitoring plan. Typically, monitoring objectives fall into one or more of the following categories (NFESC, 2000):

- Validate the conclusions of a remedial investigation/ feasibility study;

- Determine if contamination is migrating off site or off base;

- Determine if contamination will reach a receptor (such as a drinking water supply well);

- Track contaminants exceeding some standard;

- Track the changes in shape, size, or position of a contaminant plume;

- Assess the performance of a remedial;

- Assess the practicability of achieving complete remediation;

- Satisfy regulatory requirements (such as those for site closure).

The subsurface monitoring system must consist of a sufficient number of wells that are installed at appropriate locations and depths. The number of wells and their locations are principally determined by the purpose of a monitoring program. Of course, selection of a proper monitoring system should also be based on an analysis of much information, including (Wilson, 1995):
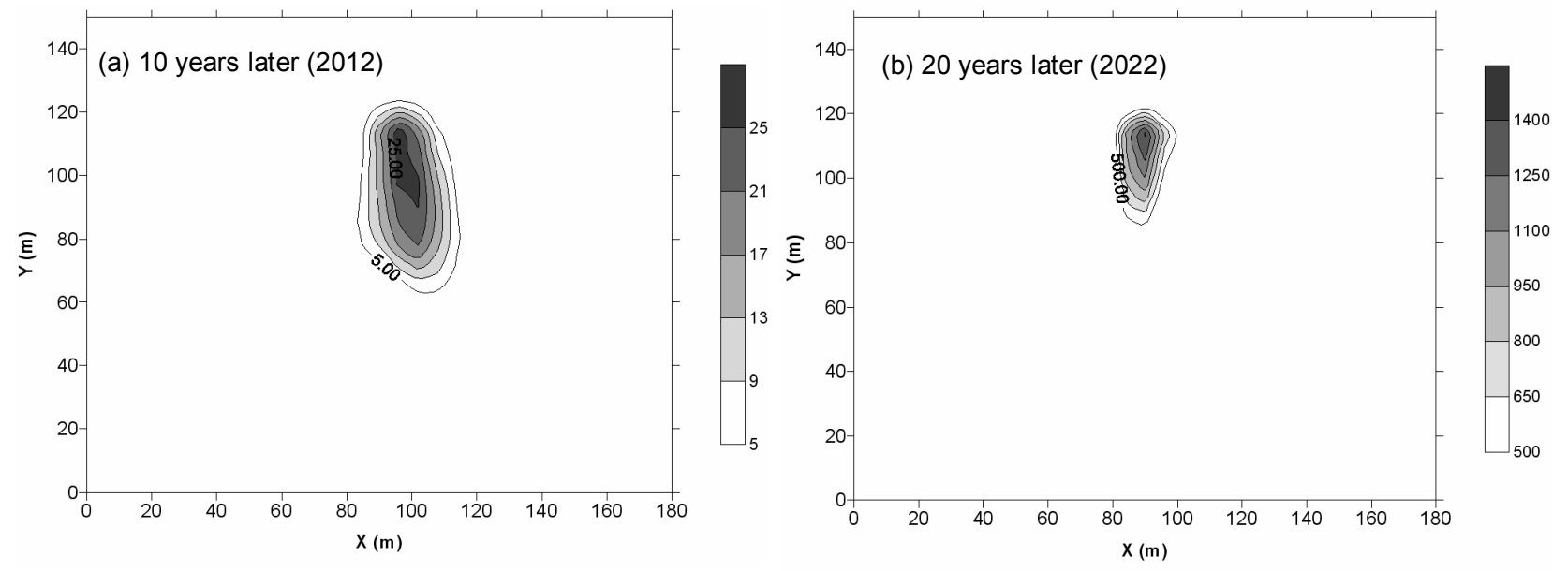

Figure 10. Predicted benzene concentrations (ppt) in groundwater under remediation option (c). 
- Nature of the contaminants;

- Soils and geology of the site;

- Distribution of contaminants in the vadose zone and aquifer;

- Aquifer characteristics including hydraulic conductivity, horizontal and vertical homogeneity, and hydraulic gradient;

- Physical and chemical characteristics of the contaminants including concentrations, solubilities, and densities;

- Environmental impacts and human health risks;

- Location of the site in the regulatory process.

Therefore, site geology, hydrology, source characteristics, contaminant characteristics, and size of the area under investigation will be needed for determining where and how many wells should be constructed. In addition, subsurface geophysical techniques can be very helpful in determining the optimum placement of monitoring wells under appropriate conditions. The more complicated the contaminant and source, and the larger the area being investigated, the more number of monitoring wells will be required. Figure 11 provides a summary of the design process for a subsurface monitoring system.

Data Analysis. Geological and hydrological factors must be known to properly design a subsurface monitoring system. The geological framework of a site includes lithology, texture, structure, mineralogy, and distribution of the unconsolidated and consolidated earth materials through which contaminants flow. The geological framework of the facility heavily influences the design of the subsurface monitoring system. Elements of the geological framework and the site hydrogeology that should be considered in a subsurface monitoring system design include:

- Spatial location and configuration of the uppermost aquifer and its hydraulic properties;

- Hydraulic gradient within the geologic materials underlying the facility;

- Facility operational considerations.

These data are used to determine the locations of both upgradient and downgradient wells in the uppermost aquifer. Both upgradient and downgradient wells should be located in the direction of contaminant-flow pathways.

Selection of Target Monitoring Zones. The first task in the design of a subsurface monitoring system is the selection of the target monitoring zones. The target monitoring zones will provide a high level of certainty that releases from the facility will be "immediately" detected. The concept of the target-monitoring zone was developed as a means of directing the subsurface-monitoring-system designer toward placement of well screens in the uppermost aquifer at locations and depths that would have the highest likelihood of detecting leakage from a facility. The target zone selection process can be described as a 4-step series:

(a) Locate site features on a topographic base map format so as to define the location of important facility components in relation to the distribution of surficial materials;

(b) Cross section construction and conceptual model development - The base grade of the facility should be plotted on cross sections to establish if any excavations at the facility intersect sensitive geological units or contaminant flow pathways. A conceptual model should be constructed to establish the site geological framework and to illustrate the distribution of geological materials of differing hydraulic conductivity;

(c) Use flow net to define likely direction of contaminant flow - Construction of flow nets will assist in defining the gradient and direction of contaminant flow in the uppermost aquifer;

(d) Select target monitoring zones - The zone which shows primarily horizontal contaminant movement under or adjacent to the facility would represent the target monitoring zone. This zone would probably represent a permeable unit that is discharging to other permeable units or to local discharge areas and the target zone is the proper location for placement of monitoring wells.

Location of Monitoring Wells. After the selection of the target monitoring zones, the next step in the design of a subsurface monitoring system is the location of monitoring wells. In general, monitoring wells should be chosen (or installed) in such a way that they:

- Provide background levels of contaminants of concern;

- Bound the horizontal and vertical extent of contaminant plumes;

- Assess bulk movement of the plume;

- Provide feedback on performance of both active and passive remedial measures.

The numbers of wells installed at a site will be based on size of facility, geological/hydrological conditions, contamination situation, and environmental criteria. Upgradient wells are placed hydraulically upgradient of the site and are capable of yielding samples that are representative and not affected by the regulated facility, and the number of upgradient wells is at least one. Downgradient wells are installed hydraulically downgradient at the limit of the waste management area. Their number, locations, and depths must ensure that they immediately detect any statistically significant amounts of hazardous wastes that migrate from the waste management area to the uppermost aquifer.

Where applicable and feasible, source areas or hotspots should be monitored to assess whether a source zone is still feeding the plume in question. The design may also include monitoring extraction or treatment wells to track performance of a remedial system. It is very important to design flexible monitoring network to allow for continual reassessment of program needs. It may be needed to have extra wells for: (1) accurately determining groundwater levels and flow direction at a site; (2) later monitoring as the plume size and shape change; and (3) contingency, in the case of damage to program wells. In evaluating placement of 


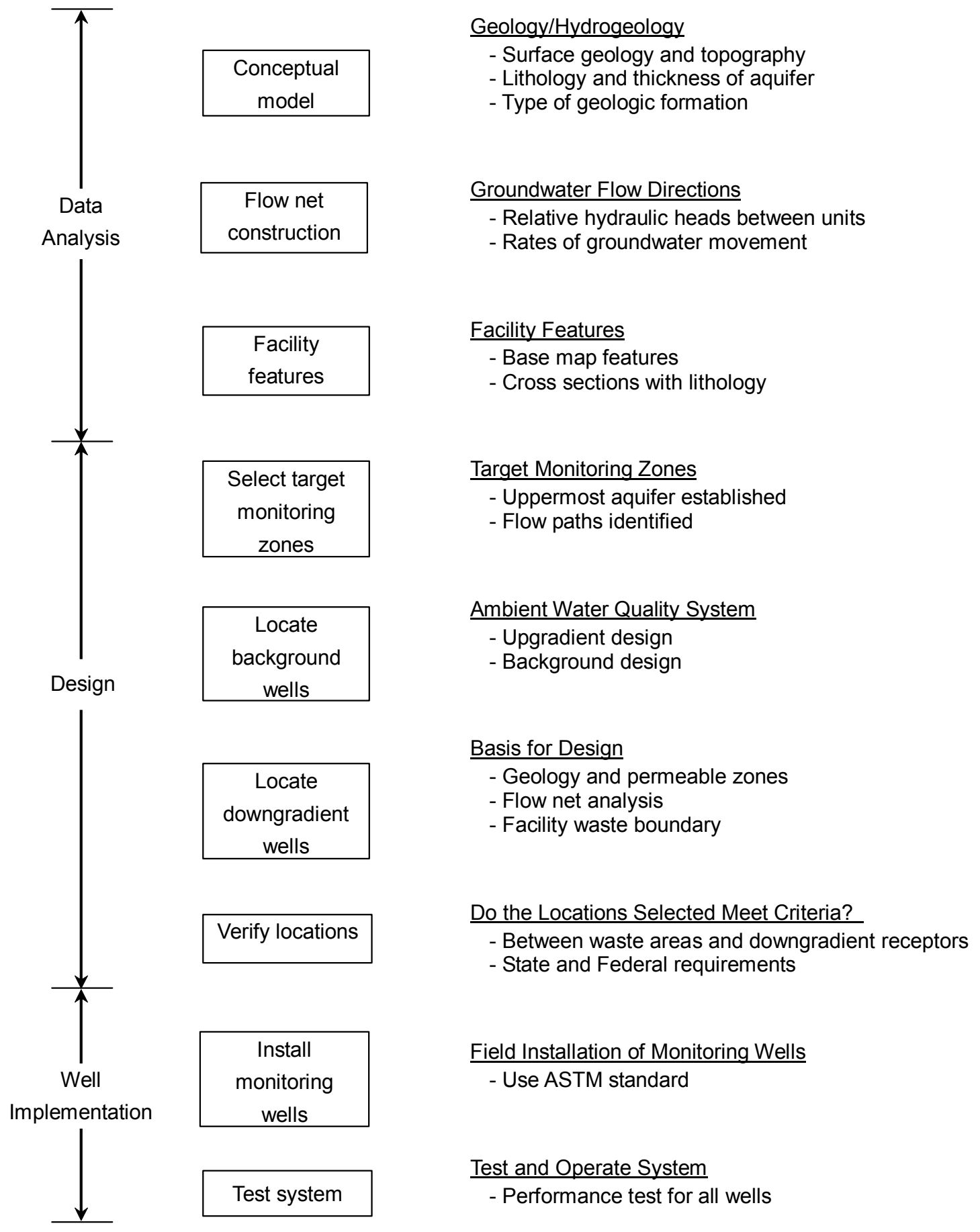

Figure 11. Design process for a groundwater monitoring system. 
monitoring wells, groundwater-flow calculations may provide insight into where contamination is likely to transport, or how potential off-site hydraulic influences such as a pumping well might change future groundwater gradients at a site.

Monitoring Frequency and Duration When starting a new monitoring program, it is often a good idea to collect four rounds of quarterly data, particularly if investigation data at a site are limited (e.g., only one round of sampling, or only one time of year) or obsolete (e.g., more than three years old). Four quarters of data will help establish the presence of any temporal (such as seasonal) and spatial variability. In addition, four data points are often considered the minimum for conducting any sort of statistical evaluation. Following the first year of quarterly data collection, monitoring frequency may be reduced as appropriate. It is essential that all monitoring data be collected using the same sampling and analytical methods to ensure comparability. If a recent, well designed site investigation has been conducted, starting a monitoring program with semiannual or even annual monitoring may be more appropriate. The purpose of a well should be taken into account when determining the sampling frequency. Downgradient, plume-edge wells generally require more frequent sampling than an upgradient or background well. Special purpose wells, such as sentinel wells, may need to be sampled often to safeguard human health.

Calculations can be used to estimate the rate of groundwater flow at a site. Although the rate of contaminant movement is usually not as fast as groundwater movement, the use of simple flow equations can provide a conservative estimate of how long it will take contamination to reach a particular point, such as the installation boundary or a supply well. This information can then be used to determine an appropriate sampling frequency and duration. Additionally, if contamination is not detected in downgradient wells within a reasonable timeframe based on flow calculation results, it may be determined that contamination will not reach the site boundary and monitoring may be discontinued. The sample-exit criterion for such a case would be any well where contamination is not detected over the course of three travel times (i.e., the estimated or modeled time that it would take for the contaminant to travel from the source area to the well) would no longer be monitored.

By identifying data trends at a site, the most appropriate sampling frequency can be proposed. If a simple concentration versus time plot of the data indicates that concentration trends in target contaminants are not changing rapidly, monitoring may be decreased to semiannually. Following a year of semiannual data collection, a similar analysis can be made to see if a reduction to annual monitoring might be implemented. If the trends of concentration over time are not clear, it may be helpful to conduct temporal trend analysis using the statistical methods. Temporal trend analysis methods typically include plotting a well's chemical concentrations as a function of time and identifying a trend by using the Mann-Kendall trend test or a regression analysis.
Trend analysis or statistics may also be used to support a decision to stop monitoring at a well or a site if contaminant concentrations are found to be stable over a long period. It may be possible to show statistically that there is not a significant difference between upgradient and downgradient concentrations of target contaminants at a site. In this case, it may also be appropriate to stop monitoring at the site. After each sampling event, or at least annually, the objectives of the groundwater-monitoring program should be reevaluated. It will determine if any of the decision criteria for reducing the frequency or duration of monitoring at a site or individual monitoring point have been met.

Identification of Analytes for Monitoring. Including only the necessary compounds in the site's analyte list reduces analytical costs, but also data management, validation, interpretation, and reporting costs. Even if receiving data for the total analyte list of a given method is no more costly than receiving data for only certain analytes, it is beneficial to eliminate the extra analytes. Including only the analytes of interest results in clearer, more concise reports.

To determine which contaminants to monitor during the initial rounds of the groundwater-monitoring program, the following information should be reviewed:

- Site history;

- Historical analytical data for both soils and groundwater at the site;

- Historical analytical data from upgradient sites that may impact groundwater quality;

- Regulatory criteria applicable to groundwater monitoring at the site;

- Background concentrations of potential target analytes in uncontaminated soil and water; and

- Results of previous baseline risk assessments performed at the site.

If a risk assessment was conducted for the site, the results would be valuable in determining which contaminants to be monitored. If any of the site contaminants were found to pose a risk to human health and/or the environment, they should be included in the initial monitoring program. Contaminants that were found to pose no risk may have a strong basis for elimination from the program. As monitoring progresses, the list of analytes for a site to focus only on contaminants of concern and associated degradation products could be reduced.

\subsection{Methods for the Design of Monitoring Systems}

Several methods are available for the design of a monitoring system. The most commonly used methods are briefly described in the following subsections.

Method 1. This method is to divide the site area into many grid cells, and the wells are located at every polygon. All the cells have the same area. A random site is chosen in each polygon. This approach will provide sufficient data for a broad assessment of subsurface contamination. However, 
it will lead to many wells with a high cost (Figure 12).

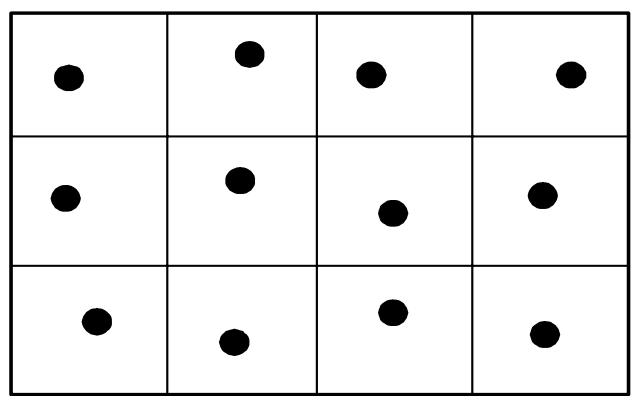

Legend:

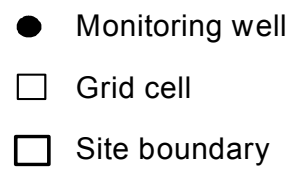

Figure 12. A subsurface monitoring system.

Method 2. In a contaminated site, most dissolved constituents will descend vertically through the unsaturated zone beneath the area of activity and then, upon reaching the saturated zone, move horizontally in the direction of contaminant flow. The LNAPL will float on top of the water table if it is present in a separate fluid phase.

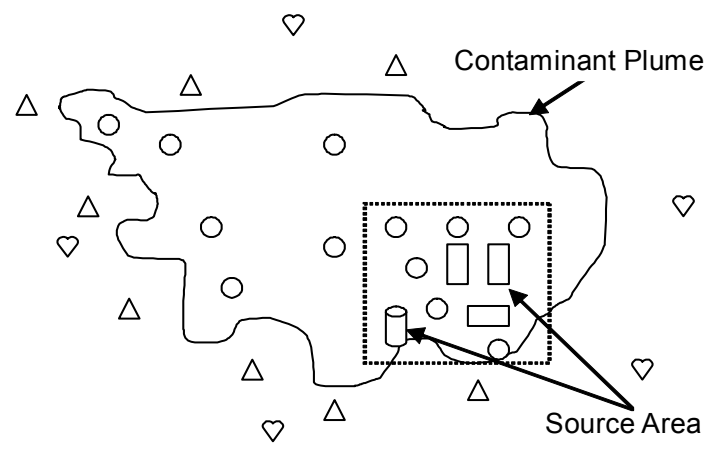

Legend:

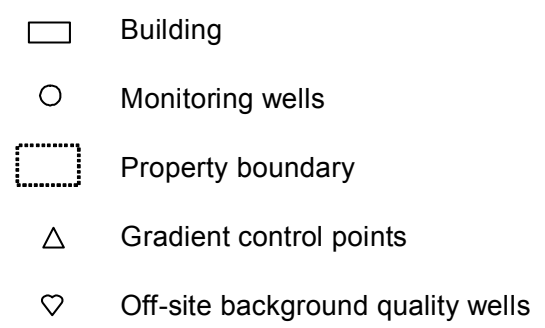

Figure 13. A compliance monitoring system.

In most situations, the monitoring goal is to determine the effect that some surface and near-surface activity has had on the nearby aquifer. Therefore, a subsurface monitor- ing system must be capable of yielding representative soil/ groundwater samples for analysis. An example of such a monitoring system is showed in Figure 13. This monitoring system consists of:

- Background monitoring wells - These monitoring wells are located at a short distance upgradient or downgradient of the plume, although cross-gradient locations may also be established. The upgradient monitoring wells are installed early in the site-investigation for the purpose of determining the quality of uncontaminated groundwater, and the downgradient monitoring wells are installed after the boundary of the contaminant plume has been defined.

- Gradient-control monitoring well - These wells are established specifically to determine the directions and magnitudes of horizontal and vertical hydraulic gradients, and they are located just outside the perimeter of the plume.

- Within-plume monitoring wells - Monitoring within the plume is important, as it facilitates management of the future remediation. Within-plume monitoring is subdivided into (a) on-site plume monitoring wells that are located within the property boundary of the facility that contains the sources of the contaminant plume, and (b) off-site plume monitoring wells that are located beyond the facility boundary but within the boundary of the plume.

Method 3 This method suggests that a successful approach for designing a subsurface monitoring system is to install an initial grid consisting of 5 or 6 wells, which monitor the upper $3 \mathrm{~m}$ of the saturated zone.

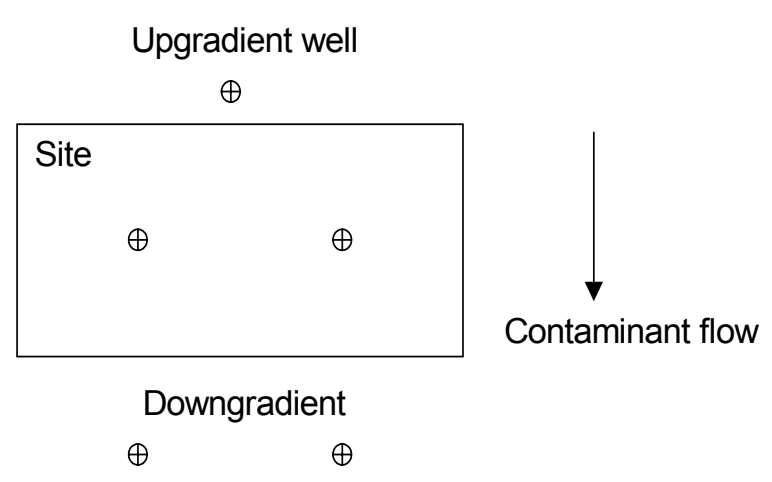

Figure 14. Typical locations for the initial wells at a site where contaminant flow direction is clearly defined.

If the groundwater flow direction within a site is clear, the typical layout for the 5 initial wells is illustrated in Figure 14. One well is located immediately upgradient of the site, two wells are located in the site, and another two are located 3 to $30 \mathrm{~m}$ downgradient. In some instances, where the direction of groundwater flow within the site is not 
known or maybe temporally or spatially variable, the well network may be placed on each side of the site as illustrated in Figure 15. If residues are found in groundwater, then this well network is expanded as needed by adding additional wells. The direction of groundwater flow and the pattern of residues in the monitoring wells can be used to select the location and depth of additional wells.

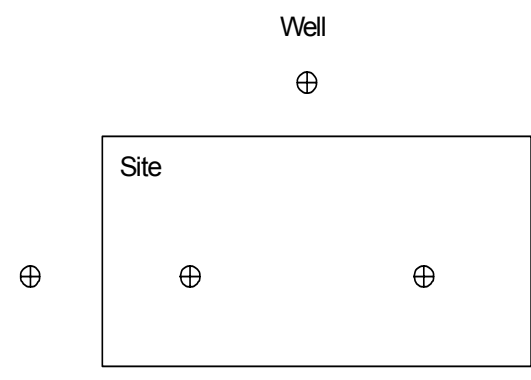

$\oplus$

$\bigoplus$

Figure 15. Alternate design for locating initial monitoring wells for use at a site with no clearly defined contaminant flow direction.

\subsection{Optimization of Monitoring Network}

On an annual basis, the objectives of the groundwatermonitoring program should be reevaluated. If the value of the information provided by a monitoring point does not justify the cost of collecting and analyzing the samples, then it may be appropriate to eliminate this monitoring point from the monitoring network. However, elimination of monitoring points must be conducted while keeping regulatory and community concerns in mind (AFCEE, 1997).

Decision Criteria Decision criteria are an important tool for optimizing a monitoring program. Decision criteria set predetermined requirements for deciding when an action will take place. Ultimately, decision criteria will provide the mechanism for ending the monitoring program at a site.

Statistical Tools for Optimization Several statistical tools can be used to optimize the number of monitoring wells necessary to achieve the program goals. Geostatistics and temporal trend analysis are appropriate statistical methods for optimization. Geostatistical methods are used to evaluate the spatial pattern and correlation of contamination across a region, allowing observing which locations continue to have unacceptably high concentrations. Regression analyses can identify trends (typically linear trends) by determining if the regression model provides a good fit and by identifying how strongly concentrations correlate with time.

Well Abandonment After monitoring has been established at a site, an evaluation of monitoring points for potential abandonment should be made. While it is important to ensure that an adequate number of monitoring points are maintained at the site to allow continual reassessment of the program. It is equally important to eliminate points that do not address program objectives and are unlikely to in the future. Proper well abandonment:

- eliminates the physical hazard of the hole in the ground;

- eliminates a conduit for migration of contamination; and

- prevents hydrologic changes in the aquifer system, such as the changes in hydraulic head and the mixing of water between aquifers.

Abandoning monitoring wells that are inappropriately screened, damaged, or dry also reduces well maintenance costs. Well abandonment must be conducted in accordance with applicable regulations, and must be reported to the proper authority.

\section{Monitoring Design for the Cantuar Site}

Conceptual Model The methodology for the monitoring design is presented in Figure 16. The site has been drilled with 48 boreholes from 1997 to 2000. Of 48 boreholes, 18 drilled in the initial monitoring (phase I) program, 15 in phase II, 9 in phase III, 4 in Phase IV and 2 in the last phase (phase V). The well locations and approximate lateral extent of contaminants are mapped in the site conceptual model. According to previous site investigations, the clay/till layer has a high gradient from east to west (including northwest and southwest). Thus, the main moving direction of free phase NAPL and its constituents is towards west with a slight gradient to northwesterly

Statistical Trend Analysis Trend analyses are performed to illuminate systematic patterns by plotting benzene concentrations and free-product thicknesses as a function of time. Trends are identified by using the regression analysis, which includes a trendline, equation of the trendline and $\mathrm{R}^{2}$ (correlation coefficient between the concentration line and trendline) value as shown in Figure 17. Moreover, a line of the SERM criteria is drawn across the plots to compare benzene concentration with the SERM criteria for potable groundwater.

Trendlines as shown in Figure 17 indicate that benzene concentrations are increasing in well BH111 and thus are exceeding the SERM criteria. The $\mathrm{R}^{2}$ value $(0.09)$ points out poor correlation between the concentration line and the trendline, implying that benzene concentrations are changing rapidly over time. It is, therefore, necessary to include this well (BH111) in the monitoring network, if they are not spatial-redundant. Following a year of semiannual monitoring, a similar analysis can be made to see if a reduction to annual monitoring might be implemented. In comparison, a decreesing trend of concentration is found in well BH207. The concentrations are well below the SERM criteria, indicating that BH207 may be excluded from the monitoring network. Similarly, trend analyses for all monitoring wells are performed to optimize the monitoring design. 


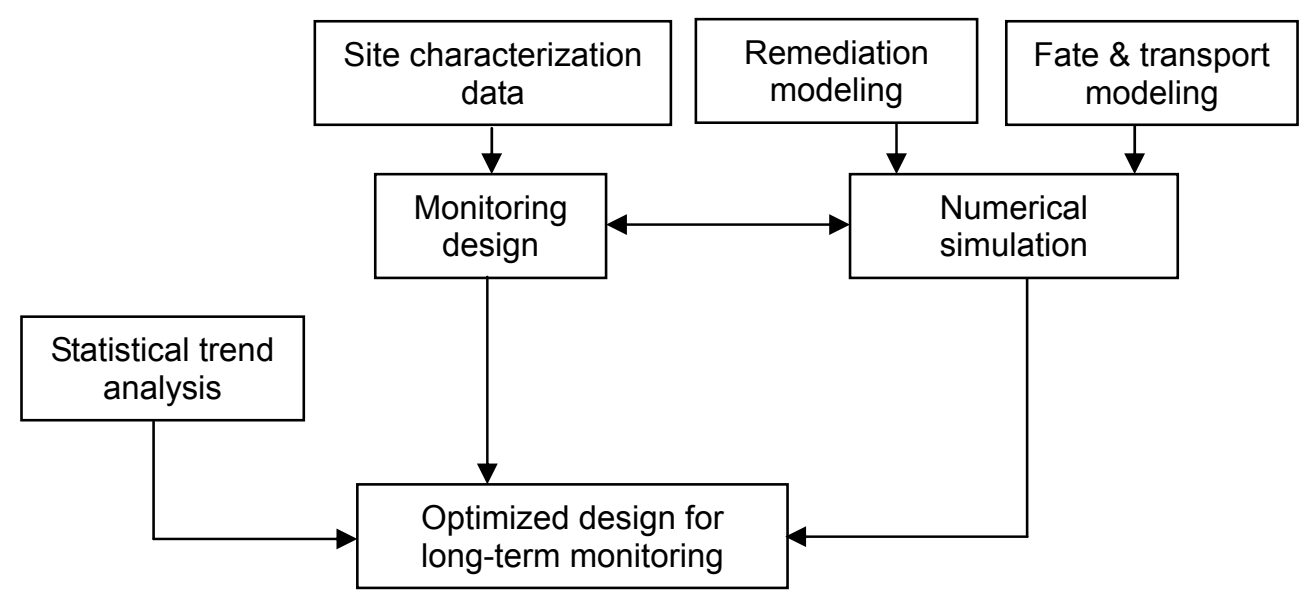

Figure 16. Monitoring design methodology.
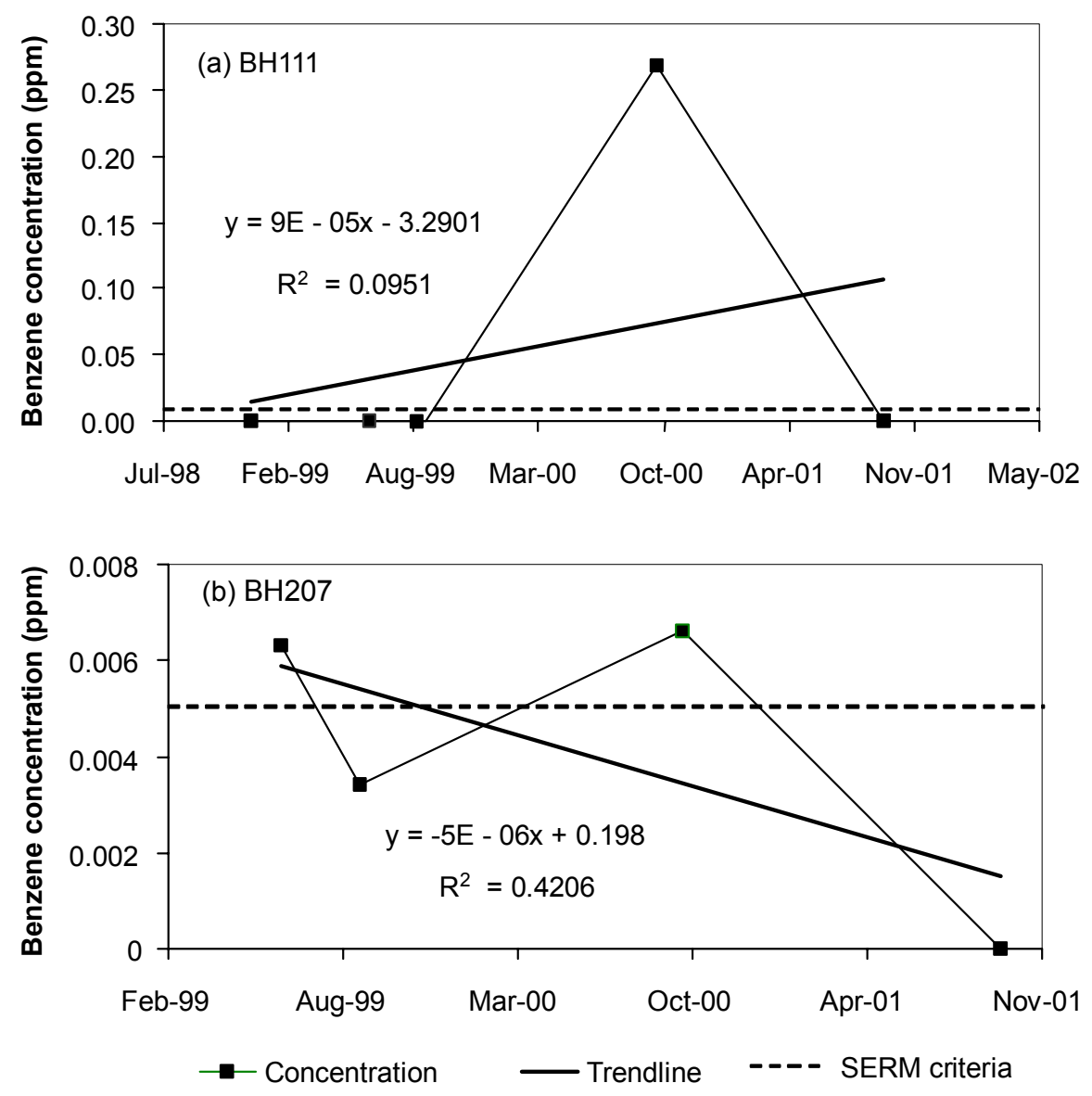

Figure 17. Groundwater benzene concentration trend in boreholes: (a) BH111 and (b) BH207. 
Sampling Location and Frequency. The sampling plan was optimized by eliminating unimportant and redundant sampling locations from the existing network first. Then the rest of potential locations are kept in the monitoring design in such a way that they (a) provide background levels of contaminants of concern, (b) bound the horizontal and vertical extent of contaminant plumes, (c) assess bulk movement of the plume, and (d) provide feedback on performance of both active and passive remedial measures. Considerations in determining sampling locations, from the existing network, for long-term monitoring at the Cantuar Site are summarized in Table 3. The minimum number of wells proposed for future sampling is ten, which includes BH103, BH105, BH106, BH107, BH110, BH111, ВH201, BH203, BH209, and BH304.

The monitoring wells and their associated locations with respect to former UST are listed in Table 4. Among the proposed monitoring wells, wells $\mathrm{BH} 103, \mathrm{BH} 105, \mathrm{BH} 106$, $\mathrm{BH} 107, \mathrm{BH} 110, \mathrm{BH} 111, \mathrm{BH} 201$, and $\mathrm{BH} 203$ are located inside the zone of free product. These monitoring wells will work together for monitoring contamination at the pollution source and its closely surrounding areas. In comparison, wells BH209 and BH304 are located in non-concentrated zones in the eastern and western directions of the leaking UST. These two wells will monitor any potential contaminant transporting into or out of the site.

For long-term monitoring at the site, the network is designed to reduce the sampling frequency for each sampling location based on the analysis of time-series data by assessing the rate of change and concentration trend of each contaminant and considering both recent and overall trends of the data. Three types of sampling frequencies including semiannual (6-month), annual and biennial (every 2-year) for the first, second and later years, respectively, are proposed for the site, with the details shown in Table 5.

Sampling Depth. The sampling points in vertical direction for each well are shown in Figure 18. The distance between two sampling points is $3 \mathrm{~m}$. For well BH000, 10 sampling points are needed. For the other wells (when groundwater is not found), only 8 points are required. When groundwater is found in well $\mathrm{BH} 000$, the number of the vertical sampling points will then be dependent on the level of groundwater table.

Sampling Analytes. The most important and representtative parameters to be analyzed for soil and groundwater are total petroleum hydrocarbons (TPH) and benzene. It is very likely that meeting of the SERM criteria by these two parameters will assume that other parameters are also within the SERM limits.

Network Design. Based on the methodologies described above, an integrated monitoring plan with two options is proposed for the Cantuar Site. The proposed sampling locations, monitoring frequencies, and constituents of concern under the two options are presented Table 4. The two options are similar to each other, except that three addi- tional wells (BH103, BH209 and BH304) are included in option 2. In option 1, eight wells are selected for future monitoring including BH105, BH106, BH107, BH110, $\mathrm{BH} 111, \mathrm{BH} 201, \mathrm{BH} 203$, and $\mathrm{BH} 401$. The location of the above sampling points is shown in Figure 19.

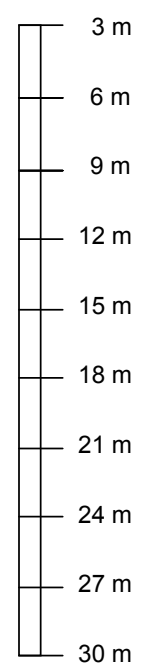

Figure 18. Vertical distribution of BH000 sampling points.

In option 2, eleven wells are considered for future sampling including BH103, BH105, BH106, BH107, BH110, BH111, BH201, BH203, BH209, BH304, and BH401. The location of the above wells is presented in Figure 20. Among the proposed monitoring wells, wells BH103, BH105, BH106, BH107, BH110, BH111, ВH201, ВH203, and $\mathrm{BH} 401$ are located inside the zone of free product. These monitoring wells will work together for monitoring contamination at the pollution source and its closely surrounding areas. In comparison, wells BH209 and BH304 are located in non-concentrated zones in the eastern and western directions of the former leaking underground storage tank. These two wells will monitor any potential contaminant transporting into or out of the site.

Both options 1 and 2 are designed through considering the following research efforts:

- The site strategraphy was thoroughly analyzed before the design.

- The monitoring network is designed for obtaining information of concentration gradient in the directions of contaminant movement.

- The sampling locations reflect the mainstream movement and extension of the contaminants.

- The design is proposed based on the existing site infrastructure. The two proposed options are cost- effective considering that the obtained data will satisfy many requirements for further modeling, assessment and remediation studies in the coming years. 
Table 3. Determination of Sampling Locations for Future Monitoring at the Cantuar Site

\begin{tabular}{|c|c|c|c|c|}
\hline Existing Well & Well Type & $\begin{array}{l}\text { Well Location } \\
\text { (relative to source) }\end{array}$ & $\begin{array}{l}\text { Well } \\
\text { Eliminated? }\end{array}$ & Consideration in Designing a Monitoring Network \\
\hline BH101 & In-Plume & Crossgradient $(\mathrm{N})$ & Yes & Redundant to BH103 sampling location \\
\hline BH102 & Crossgradient & Crossgradient (S) & Yes & Out-of-plume \\
\hline BH103 & In-Plume & Downgradient (SW) & No & Remediation progress \\
\hline BH104 & In-Plume & Crossgradient $(\mathrm{N})$ & Yes & Redundant to BH107 \\
\hline BH105 & In-Plume & Downgradient (W) & No & Remediation progress \\
\hline BH106 & In-Plume & Downgradient (W) & No & Remediation progress \\
\hline BH107 & In-Plume & Crossgradient $(\mathrm{N})$ & No & Dispersion of the contaminants \\
\hline BH108 & In-Plume & Downgradient (NW) & Yes & Redundant to $\mathrm{BH} 111$ and $\mathrm{BH} 203$ \\
\hline BH109 & Background & Upgradient (NE) & Yes & Redundant to BH209, Out-of-plume \\
\hline BH110 & In-Plume & Downgradient (SW) & No & Remediation progress \\
\hline BH111 & In-Plume & Downgradient (NW) & No & Remediation progress \\
\hline BH112 & Background & Crossgradient (NE) & Yes & Out-of-plume, redundant to $\mathrm{BH} 209$ \\
\hline BH113 & Background & Crossgradient (NE) & Yes & Out-of-plume, redundant to $\mathrm{BH} 209$ \\
\hline BH201 & In-Plume & Downgradient (W) & No & Migration of the contaminants / Plume movement \\
\hline BH202 & In-Plume & Downgradient (W) & Yes & Redundant to BH111 \\
\hline BH203 & In-Plume & Downgradient (NW) & No & Remediation progress / Plume movement \\
\hline BH204 & Plume-Edge & Downgradient (NW) & Yes & Redundant to $\mathrm{BH} 203$ and $\mathrm{BH} 304$ \\
\hline $\mathrm{BH} 205$ & Plume-Edge & Downgradient (NW) & Yes & Redundant to $\mathrm{BH} 203$ \\
\hline BH206 & Downgradient & Downgradient (NW) & Yes & Out-of-plume \\
\hline BH207 & Plume-Edge & Crossgradient $(\mathrm{N})$ & Yes & Redundant to BH107 \\
\hline BH208 & Plume-Edge & Downgradient (SW) & Yes & Redundant to BH110 \\
\hline ВH209 & Upgradient & Upgradient (E) & No & On-site migration of background concentrations \\
\hline BH301 & Downgradient & Downgradient (W) & Yes & Out-of-plume, Redundant to BH201 \\
\hline ВH302 & Crossgradient & Crossgradient (SW) & Yes & Out-of-plume \\
\hline BH303 & Downgradient & Downgradient (W) & Yes & Redundant to BH304, Out-of-plume \\
\hline BH304 & Downgradient & Downgradient (W) & No & Migration of the contaminants / Plume movement \\
\hline BH401 & In-Plume & Crossgradient $(\mathrm{N})$ & No & Redundant to BH103 sampling location \\
\hline BH402 & In-Plume & Crossgradient (SW) & Yes & Redundant to $\mathrm{BH} 103$ \\
\hline
\end{tabular}

Note: $\mathrm{E}=$ East $\mathrm{W}=$ West, $\mathrm{N}=$ North, $\mathrm{S}=$ South, $\mathrm{NE}=$ North East, $\mathrm{NW}=$ North West, $\mathrm{SE}=$ South East, $\mathrm{SW}=$ South West 
Table 4. Sampling Locations, Monitoring Frequencies, and Monitoring Constituents for Future Monitoring at the Cantuar Site

\begin{tabular}{|c|c|c|c|c|}
\hline No. & Well Name & Well Type & Well Location (relative to former UST) & Sampling Frequency \\
\hline 1 & $\mathrm{BH} 103 * \wedge$ & In-Plume & Downgradient (SW) & Annual+ \\
\hline 2 & $\mathrm{BH} 105^{* \wedge}$ & In-Plume & Downgradient (W) & Annual+ \\
\hline 3 & $\mathrm{BH} 106^{* \wedge}$ & In-Plume & Downgradient (W) & Annual+ \\
\hline 4 & $\mathrm{BH} 107 * \wedge$ & In-Plume & Crossgradient $(\mathrm{N})$ & Annual+ \\
\hline 5 & $\mathrm{BH} 110^{* \wedge}$ & In-Plume & Downgradient (SW) & Annual+ \\
\hline 6 & $\mathrm{BH} 111^{* \wedge}$ & In-Plume & Downgradient (NW) & Annual+ \\
\hline 7 & $\mathrm{BH} 201 * \wedge$ & In-Plume & Downgradient (W) & Annual+ \\
\hline 8 & $\mathrm{BH} 203 * \wedge$ & In-Plume & Downgradient (NW) & Annual+ \\
\hline 9 & BH209* & Out-of-Plume & Upgradient (E) & Annual- \\
\hline 10 & BH304* & Out-of-Plume & Downgradient (W) & Annual- \\
\hline 11 & BH $401^{* \wedge}$ & In-Plume & Crossgradient $(\mathrm{N})$ & Annual+ \\
\hline
\end{tabular}

Note: * monitoring option $1 ; \wedge$ monitoring option $2 ; \mathrm{E}=$ East, $\mathrm{W}=$ West, $\mathrm{N}=$ North, $\mathrm{NW}=$ North West, $\mathrm{SW}=$ South West, Annual $+=$ Annual or more frequent (e.g., every 6 months); Annual- $=$ Annual or less frequent (e.g., every 2 years)

Table 5. Sampling Frequency for Long-term Monitoring at the Cantuar Site

\begin{tabular}{|c|c|c|c|c|c|}
\hline \multirow[b]{2}{*}{ Constituent } & \multirow[b]{2}{*}{ Well Name } & \multirow[b]{2}{*}{ Well Type } & \multicolumn{2}{|c|}{ Sampling Frequency } & \multirow[b]{2}{*}{ Later Years } \\
\hline & & & First Year & Second Year & \\
\hline \multirow[t]{10}{*}{ TPH and Benzene } & BH103 & In-Plume & Semiannual & Annual & Annual- \\
\hline & BH105 & In-Plume & Semiannual & Annual & Annual- \\
\hline & BH106 & In-Plume & Semiannual & Annual & Annual- \\
\hline & BH107 & Crossgradient & Semiannual & Annual & Annual- \\
\hline & BH110 & In-Plume & Semiannual & Annual & Annual- \\
\hline & BH111 & In-Plume & Semiannual & Annual & Annual- \\
\hline & BH202 & In-Plume & Semiannual & Annual & Annual- \\
\hline & BH203 & In-Plume & Semiannual & Annual & Annual- \\
\hline & BH209 & Upgradient & Annual & Annual- & Biennial \\
\hline & BH304 & Downgradient & Annual & Annual- & Biennial \\
\hline
\end{tabular}

Note: Annual- = Annual or less frequent (e.g., every 2 years) 


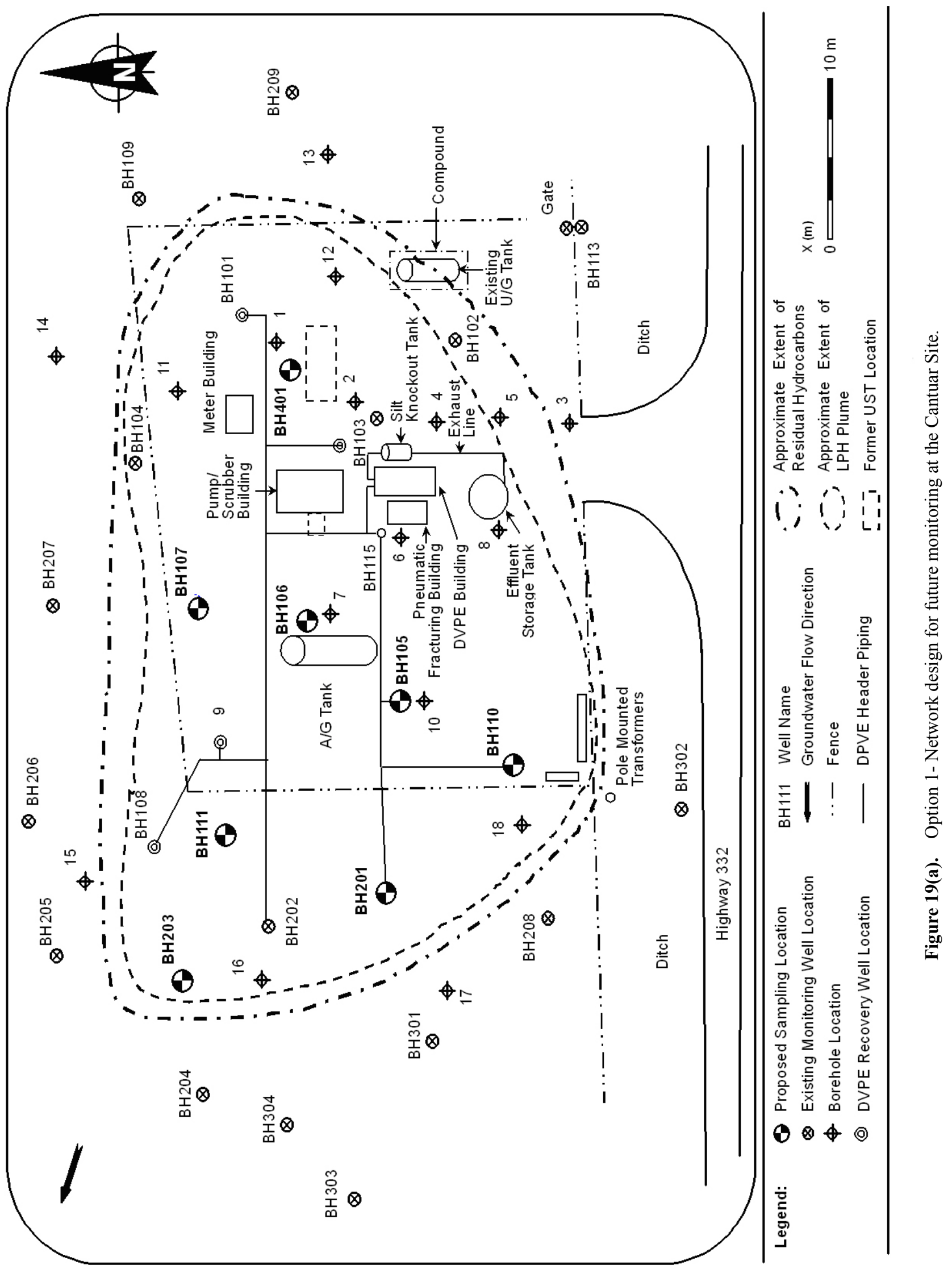




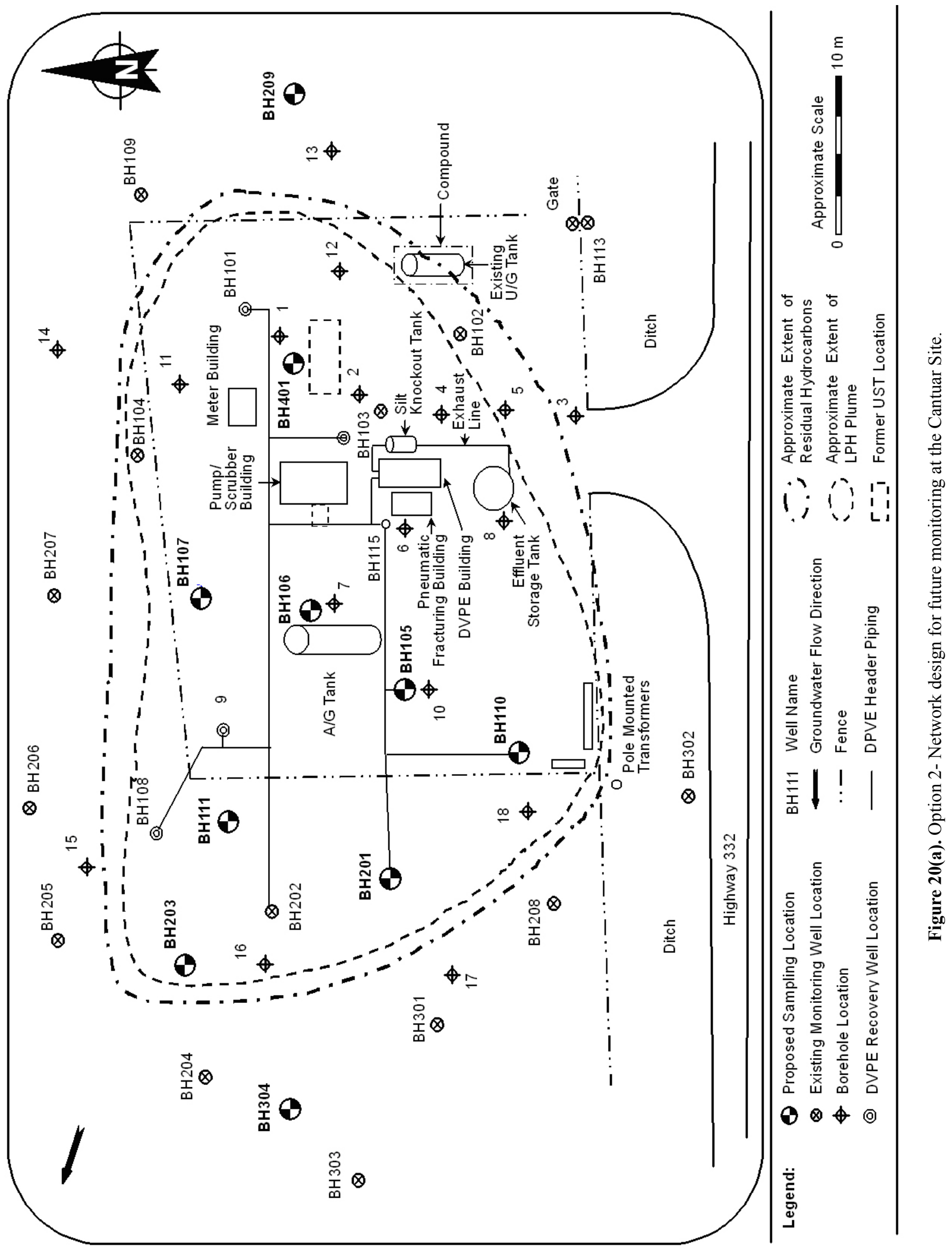




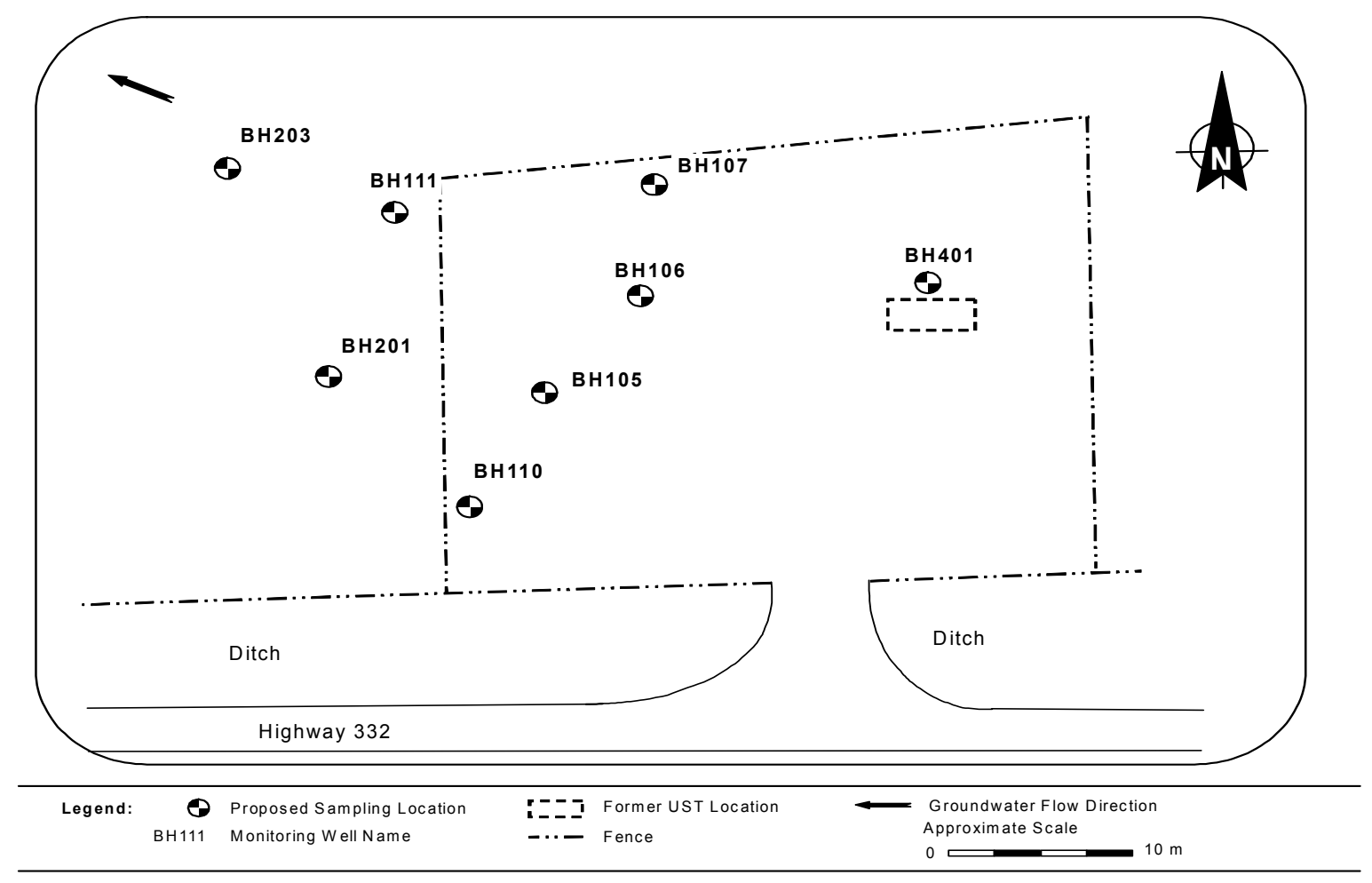

Figure 19(b). Option 1: Sampling locations for future monitoring at the Cantuar Site.

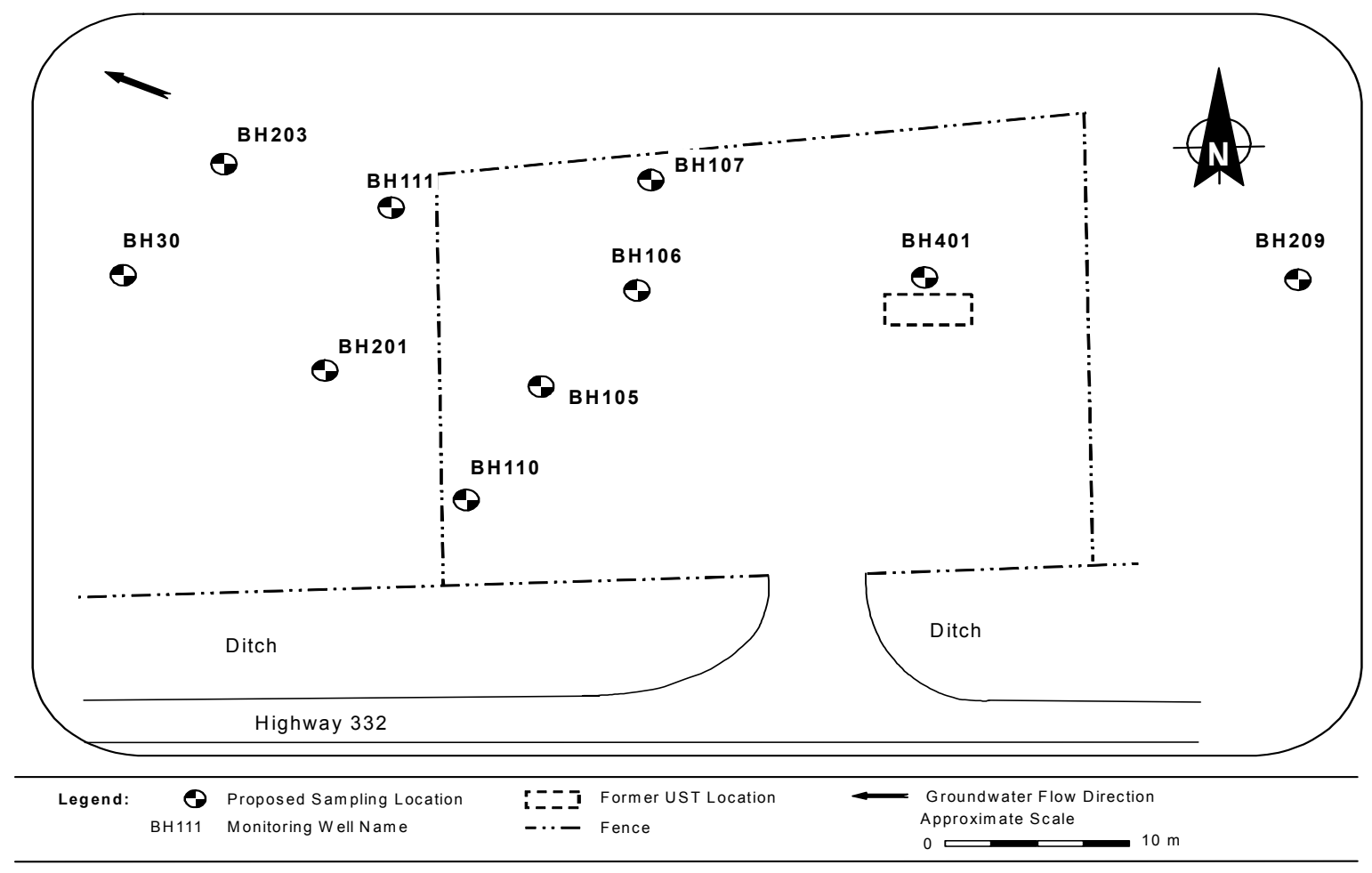

Figure 20(b). Option 2: Sampling locations for future monitoring at the Cantuar Site. 
Quality Control Quality assurance/quality control (QA/QC) procedures should be followed in the sampling process. Locations for the sampling wells should be strictly accurate. Any change beyond the standard sampling procedures must be justified, described, and approved by the appropriate project personnel. A field audit can be undertaken to ensure that $\mathrm{QA} / \mathrm{QC}$ procedures are followed. All activities in the sampling processes (including monitoring of geological, hydrological and environmental conditions) should be undertaken based on the standard excavation, sampling, storage, transportation, and analysis methods.

Recommendations The idea behind generating the two options is to give decision maker more choices. The both options can efficiently represent the site conditions. However, compared to option 1, option 2 is preferred if it is economically feasible. The advantages of option 2 include:

- It provides a more comprehensive framework for detecting plume gradient;

- It provides more information for identifying boundary of the plume and examining relations between the targeted monitoring zone and the background zone;

- It offers additional information on contaminants and naturally-occurring compounds migrating from upgradient into the site;

- It provides better support for further modeling and risk assessment studies;

- It provides better support to facilitate the monitoring performance for the subsequent remediation activities.

\section{Conclusions}

(1) An integrated approach was proposed to design groundwater monitoring through the incorporation of site characterization, simulation, optimization, statistical trend analysis, and dynamic design into a single frame. The approach was applied to design groundwater-monitoring plans for the petroleum-contaminated site in western Canada.

(2) The network plan can reflect dynamic characteristics of the site. It presents a declining pattern of sampling frequency associated with a rising trend of the site restoration. For the future monitoring, ten sampling locations were suggested with sampling frequencies of semiannual, annual and biennial for the first, second and subsequent years, respectively. Two monitoring parameters including benzene and total petroleum hydrocarbons were proposed as constituents of interests.

(3) The plan offered two monitoring options. In option 1 , eight sampling locations were proposed and; in option 2 eleven were recommended. A sampling interval of 6 months to 1 year was proposed under option 1 , and an interval of 6 months to 2 years was suggested under option 2 . The two proposed options can efficiently represent the site conditions. Compared to option 1, option 2 provides more comprehensive framework for detecting the contaminant plume and monitoring the performance of remediation activities. Option 2 is preferred if it is economically feasible. The final decision should be based on both accuracy requirement and economic consideration.

(4) The proposed sampling plans provide not only insight into the site contamination situation, but also information needed for further modeling, assessment, and remediation studies. The methodology used in this study is applicable to other contaminated sites

\section{References}

AFCEE (1997). Long-Term Monitoring Optimization GuideVersion 1.1, Air Force Center for Environmental Excellence, Consultant Operations Division, Brooks Air Force Base, San Antonio, TX, USA.

Andricevic, R. and Foufoula-Georgiou, E. (1991). A transfer function approach to sampling network, design for groundwater contamination. Water Resour. Res., 27(10), 2759-2770.

Angulo, M. and Tang, W.H. (1996). Groundwater monitoring system design using a probabilistic observation method for site characterization. Geotech. Spec. Publ., 58, 797.

Beckie, R.D. (1996). Measurement scale, network sampling scale, and groundwater model parameters. Water Resour. Res., 32(1), 65-77.

Cieniawski, S.E., Eheart, J.W. and Ranjithan, S. (1995). Using genetic algorithms to solve a multiobjective groundwater monitoring problem. Water Resour. Res., 31(2), 399-409.

Grabow, G.L., Mote, C.R., Sanders, W.L., Smoot, J.L. and Yoder, D.C. (1993). Groundwater monitoring network design using minimum well density. Water Sci. Technol., 28(3-5), 327.

Hudak, P.F. (1999). A method for designing upgradient groundwater monitoring networks. Environ. Monit. Assess., 57, 149-155.

Hudak, P.F. and Loaiciga, H.A. (1993). An optimization method for monitoring network design in multilayered groundwater flow system. Water Resour. Res., 29, 2835-2845.

Hudak, P.F. (2002). Designing equitemporal monitoring networks to detect contaminants in groundwater. Bulletin of Environmental Contamination and Toxicology, 68, 168-172.

Li, J.B., Huang, G.H., Chakma, A. and Zeng, G.M. (2003). Numerical simulation of dual-phase vacuum extraction to remove nonaqueous phase liquids in subsurface. ASCE, Pract. Periodical Hazard., Toxic, Radioact. Waste Manage., 7(2), 106-113.

Loaiciga, H.A. (1992). Review of ground-water quality monitoring network design. J. Hydraul. Eng., 118(1), 11.

Maqsood, I., Huang, G.H. and Li, J.B. (2003). Inexact multiphase modeling system for management of uncertainty in subsurface contamination. ASCE, Pract. Periodical hazard., Toxic, Radioact. Waste Manage., 7(2), 86-94.

Meyer, P.D., Valocchi, A.J. and Eheart, J.W. (1994). Monitoring network design to provide initial detection of groundwater contamination. Water Resour. Res., 30(9), 2647.

NFESC (2000). Guide to Optimal Groundwater Monitoring-Interim Final, Naval Facilities Engineering Service Center, Port Hueneme, CA, USA.

Rasula, G. and Rasula, M. (2001). Groundwater quality monitoring system in zones of infrastructure facilities. Eng. Geol., 60, 351-360.

Reed, P.M., Minsker, B.S. and Goldberg, D.E. (2001). A multiobjective approach to cost effective long-term groundwater monitoring using an Elitist Nondominated Sorted Genetic 
Algorithm with historical data. J. Hydroinf., 3(2), 71-90.

Reed, P.M., Minsker, B.S. and Valocchi, A.J. (2000). Cost-effective long-term groundwater monitoring design using a genetic algorithm and global mass interpolation. Water Resour. Res., 36(12), 3731-3743.

Ridley, M.N. and MacQueen, D. (1998). Cost-Effective Sampling of Groundwater Monitoring Wells: A Data Review and Well Frequency Evaluation, Technical Report, Lawrence Livermore National Laboratory, Livermore, CA, USA.

Rouhani, S. and Hall, T.J. (1988). Geostatistical schemes for groundwater sampling. J. Hydrol., 103, 85-102.

SERM (Saskatchewan Environment and resource Management) (2002). Risk Based Corrective Actions for Petroleum Contaminated Sites. Province of Saskatchewan, Regina, SK, Can- ada.

Wagner, B.J. (1995). Sampling design methods for groundwater modeling under uncertainty. Water Resour. Res., 31(10), 2581-2591.

Wilson, N. (1995). Soil Water and Ground Water Sampling, Lewis Publishers, London.

Zhang, Y. and Pinder, G. (2002). Design of optimal groundwater-quality monitoring networks via computer assisted analysis, in Computational Methods in Water Resources, XIV, Delft, The Netherlands, 1419-1425.

Zhou, Y. (1994). Objectives, criteria and methodologies for the design of primary groundwater monitoring networks. IAHS publication. 222, 285. 